\title{
NACHHALtige NutZUNG VON ERNEUERBAREN ENERGIEN - UNTERNEHMERISCHES INVESTITIONSVERHALTEN UND VERTRAGSGESTALTUNG
}

\author{
Dissertation \\ zur Erlangung des Doktorgrades \\ der Fakultät für Agrarwissenschaften \\ der Georg-August-Universität Göttingen
}

vorgelegt von

Dipl.-Kfm. Christian Reise

geboren in Braunschweig

Göttingen, im April 2012 
D 7

1. Referent:

Prof. Dr. Oliver Mußhoff

2. Korreferent: Jun.-Prof. Dr. Ulf Liebe

Tag der mündlichen Prüfung: $\quad$ 31. Mai 2012 


\section{Vorwort}

Die vorliegende Arbeit entstand während meiner Tätigkeit als wissenschaftlicher Mitarbeiter am Arbeitsbereich Landwirtschaftliche Betriebslehre des Departments für Agrarökonomie und Rurale Entwicklung (DARE) und im Forschungsverbundvorhaben "Nachhaltige Nutzung von Biomasse im Spannungsfeld von Klimaschutz, Landschaft und Gesellschaft" des Interdisziplinären Zentrums für Nachhaltige Entwicklung (IZNE) der Georg-August-Universität Göttingen.

Für die großartige Unterstützung, die mir während der Anfertigung dieser Arbeit widerfahren ist, möchte ich mich auf diesem Wege bei allen folgenden Personen ganz herzlich bedanken. Zuerst danke ich meinem Doktorvater und akademischem Lehrer Prof. Dr. Oliver Mußhoff, der diese Arbeit betreute und mich in allen wissenschaftlichen und finanziellen Belangen uneingeschränkt unterstützt und gefördert hat. In unzähligen Diskussionen, die auch oft spät nachts stattgefunden haben, eröffnete er mir als wertvoller Gesprächspartner viele interessante Sichtweisen. Das zeitnahe Feedback, auf das stets Verlass war, hat mir sehr weitergeholfen. Ich habe sehr gern mit ihm zusammengearbeitet. Mein Dank gilt auch Jun.-Prof. Dr. Ulf Liebe für die Übernahme des Zweitgutachtens und die Unterstützung bei dem Choice Experiment aus der zweiten Untersuchung. Er stand mir stets mit hilfreichen Anregungen zur Seite. Mein weiterer Dank gilt Prof. Dr. Hans Ruppert für die Bereitschaft zur Übernahme der Drittprüferschaft und seine engagierte Projektleitung sowie dem Projektteam, in dem ich arbeiten durfte und das mich so herzlich aufgenommen hat. Zudem gilt mein Dank auch den zahlreichen Teilnehmern unserer Befragungen. Die Arbeit wäre auch ohne die Unterstützung vieler Kolleginnen und Kollegen, die mir auf die unterschiedlichste Weise geholfen haben, nicht möglich gewesen: Insbesondere möchte ich Frau Ingeborg Brückner und Frau Jessica Olbrich meinen Dank für die technische Unterstützung aussprechen.

Großer Dank gilt auch meiner Familie. Meine Eltern Helmut und Rita und meine Großeltern Maria, Hilde und Ernst, standen immer zu mir und haben meine akademische Ausbildung auch in finanzieller Hinsicht unterstützt. Mein „kleiner Bruder“ Holger war mir - mit seiner systematischen und strukturierten Denkweise als Diplom-Informatiker - ein wertvoller Diskussionspartner, der mir jederzeit sofort verlässlich zur Verfügung stand. Meine Schwiegereltern Ina und Gunther standen mir zur Seite und waren Woche um Woche bereit, ihren Enkel Felix in meiner Abwesenheit mit zu betreuen und zu fördern. 
Schließlich gilt mein großer Dank meiner Ehefrau Alexandra, meinem Sohn Felix und unserem Neufundländer Graf von der Bernde, die mir mit Liebe und Verständnis den nötigen Abstand zu meiner Promotion an den Wochenenden verschafft haben. Ihnen möchte ich diese Arbeit widmen.

Braunschweig und Göttingen im April 2012

Christian Reise 


\section{Inhaltsverzeichnis}

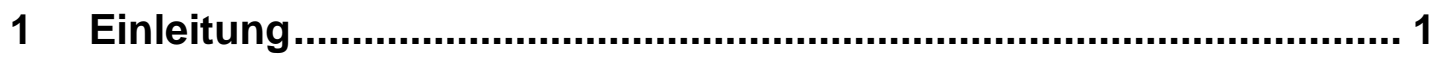

2 Untersuchung zum unternehmerischen Investitionsverhalten bei

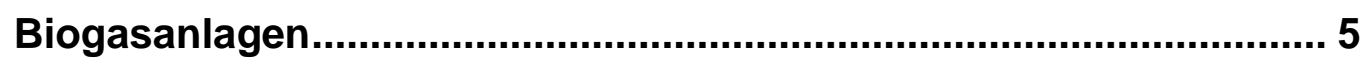

3 Untersuchung zu Verträgen für die Rohstoffversorgung von

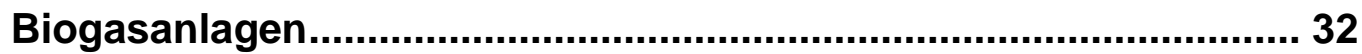

4 Zusammenfassende Darstellung und Diskussion .......................... 64

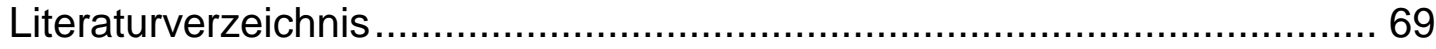

Erklärung über den geleisteten Eigenanteil an der Arbeit ............................ 70

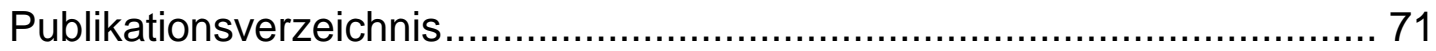

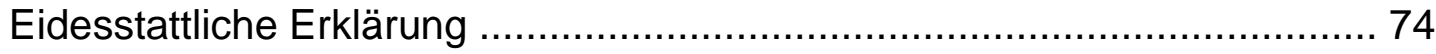


„Stop; Think then Act."

Capt. Daniel Berg (BERG 1991: 8)

\section{Einleitung}




\section{Problemstellung}

Ohne Energie kommt die Welt zum erliegen. Für die moderne Gesellschaft ist die kontinuierliche Verfügbarkeit von Energie essentiell. Im Jahr 2011 lag der Primärenergieverbrauch in Deutschland bei 13.374 Petajoule (vgl. AGEB 2012). Die Energieerzeugung hat damit eine herausragende gesamtwirtschaftliche Bedeutung. Gegenwärtig werden rund $80 \%$ des deutschen Energiebedarfs mit fossilen Rohstoffen gedeckt (vgl. AGEB 2012).

Viele Gründe sprechen für einen nachhaltigen Umbau der bestehenden Energieerzeugung. Beispielsweise ist die Menge der zur Verfügung stehenden fossilen Energieträger endlich. Viele fossile Ressourcen liegen in politisch instabilen Regionen (Versorgungssicherheit). Zudem sind fossile Energieträger - wie Kohle, Erdöl und Erdgas - bei der Nutzung klimawirksam, da diese aus Abbauprodukten toter Pflanzen und Tiere bestehen. Die Pflanzen haben bei ihrer Entstehung vor Jahrmillionen Sonnenenergie gespeichert und der damaligen Atmosphäre Kohlenstoff entzogen. Werden diese verbrannt, um die gespeicherte Energie zu nutzen, wird der gebundene Kohlenstoff wieder frei und führt zu einer Erhöhung der Kohlenstoffdioxidkonzentration in der Atmosphäre (vgl. MU 2012). Bei einer „zeitnahen Nutzung“ von Sonnenenergie im Rahmen der Bioenergieerzeugung ist der Kohlenstoffkreislauf hingegen geschlossen, da bei dieser Art der Nutzung nur Kohlenstoff freigesetzt wird, der der Atmosphäre kurzzeitig entzogen wurde. Im Hinblick auf die aktuellen Klimaziele der Bundesregierung hat der Ausbau erneuerbarer Energien größte Relevanz (vgl. z.B. BMU und BMELV 2009).

Bei der Erzeugung von Biogas - als eine Art der Bioenergieerzeugung - kommt Landwirten eine zentrale Rolle zu. Für eine Verbesserung der Politikfolgenabschätzung sowie für eine Verbesserung der einzelbetrieblichen Entscheidungsunterstützung ist es daher von großer Bedeutung, das Entscheidungsverhalten von Landwirten in Bezug auf die Erzeugung von Biogas besser zu verstehen. Veränderte Rahmenbedingungen (z.B. Novellierung des Gesetzes für den Vorrang Erneuerbarer Energien (EEG)) finden nur in dem Maße einen Niederschlag in einzelwirtschaftlichen Entscheidungen (z.B. Investition in eine Biogasanlage oder Abschluss von Rohstofflieferverträgen), in dem sie von den Akteuren auch wahrgenommen und planerisch verarbeitet werden.

Für den weiteren Ausbau der Erneuerbaren Energien ist es daher von wesentlicher Bedeutung, welche Faktoren bei unternehmerischen Investitionen in Biogasanlagen eine Rolle spielen und wie Investitionsförderungsmaßnahmen wirken. Während bei 
einer Investition in eine Biogasanlage mit eigenständiger Rohstoffversorgung der Anlagenbetreiber implizit einen Rohstoffliefervertrag mit sich selbst abschließt, ist bei größeren Anlagen oft eine (Zu-)Lieferung von landwirtschaftlichen Rohstoffen aus (anderen) landwirtschaftlichen Betrieben erforderlich. Diese ist auch bei Anlagenbetreibern notwendig, denen kein eigenes Substrat zur Verfügung steht. Vielfach sind Landwirte aufgrund steigender und volatiler Agrarpreise nicht einfach bereit, ihre unternehmerische Flexibilität durch langfristige Vertragsbindungen einzuschränken. Insgesamt kommt den Substratkosten eine erhebliche Bedeutung zu, da diese rund die Hälfte der jährlichen Kosten einer Biogasanlage ausmachen (vgl. z.B. WALLA und SCHNEEBERGER 2008). Wenn das notwendige Substrat für die langfristige Sicherstellung der Rohstoffversorgung einer Biogasanlage fehlt, sind zudem Banken nicht gewillt, Kredite zu gewähren. Daher muss der Schnittstelle zwischen Substratanbauern und Biogasanlagenbetreibern besondere Beachtung geschenkt werden.

\section{Zielsetzung}

Vor diesem Hintergrund soll die vorliegende Dissertation zu Erkenntnissen über das unternehmerische Investitionsverhalten von landwirtschaftlichen Betriebsleitern bei Biogasanlagen beitragen, um die unterschiedliche Umsetzung von Investitionen in Biogasanlagen genauer zu verstehen und so u.a. die Konsequenzen bestimmter Politikmaßnahmen besser abschätzen zu können. Zudem sollen aus der Substratverkäuferperspektive von landwirtschaftlichen Betriebsleitern wesentliche Faktoren für den Abschluss von Verträgen für die Rohstoffversorgung von Biogasanlagen aufgezeigt werden. Dabei sollen Aussagen zur Bedeutung von ausgewählten Vertragsbestandteilen abgeleitet werden.

Konkret wird folgenden Fragestellungen nachgegangen:

1. Welche Faktoren sind bei Investitionsentscheidungen in Bezug auf Biogasanlagen für landwirtschaftliche Unternehmer von Bedeutung?

2. Wie sehen die Präferenzen landwirtschaftlicher Betriebsleiter hinsichtlich der Ausgestaltung von Rohstofflieferverträgen für Biogasanlagen aus der Substratverkäuferperspektive aus?

Zusammenfassend soll die Dissertation zu weiteren Erkenntnissen hinsichtlich der komplexen Entscheidungsfindungsprozesse von wirtschaftlichen Akteuren führen, Entscheidungsunterstützung auf einzelbetrieblicher Ebene leisten und im Rahmen 
der Politikfolgenabschätzung weitere Voraussetzungen für einen nachhaltigen Ausbau von Bioenergie schaffen.

\section{Aufbau der Dissertationsschrift}

In Anlehnung an die zuvor genannten Forschungsfragen ist der Hauptteil der vorliegenden Dissertationsschrift in zwei Bereiche untergliedert, in denen bereits veröffentlichte bzw. zur Veröffentlichung angenommene Beiträge vorgestellt werden. Im nachfolgenden Kapitel 2 wird eine Untersuchung zum unternehmerischen Investitionsverhalten bei Biogasanlagen vorgestellt. Als Untersuchungsbasis wurde die Befragung „Investitionsverhalten Bioenergie“ durchgeführt. Die Ergebnisse wurden zunächst auf nationalen und internationalen Tagungen vorgestellt und anschließend auf Basis von Anregungen weiterentwickelt. Die abschließende Veröffentlichung erfolgte in der Zeitschrift Ecological Economics. In Kapitel 3 wird eine Untersuchung zu Verträgen für die Rohstoffversorgung von Biogasanlagen präsentiert. Als Grundlage der Untersuchung wurde die Befragung "Gestaltung Substratlieferverträge" durchgeführt. Nach der Vorstellung der Untersuchungsergebnisse auf einer nationalen und einer internationalen Tagung wurden diese weiter ausgebaut und im German Journal of Agricultural Economics zur Veröffentlichung angenommen. Die Arbeit schließt mit einer zusammenfassenden Darstellung der bearbeiteten Themen und einer Diskussion (Kapitel 4). 


\section{Untersuchung zum unternehme- rischen Investitionsverhalten bei Biogasanlagen}




\title{
Which Factors Influence the Expansion of Bioenergy? An Empirical Study of the Investment Behaviours of German Farmers
}

\author{
Christian Reise, Oliver Mußhoff, Karol Granoszewski, Achim Spiller
}

Dieser Beitrag ist in Ecological Economics (2012), Band 73, Heft C auf den Seiten 133 bis 141 erschienen.

\begin{abstract}
The German government is planning to increase the share of renewable energy sources. In this context, it is important to understand the decision-making behaviour of farmers regarding investments in renewable energy systems that generate energy from biomass and farmers' reactions to investment-support measures. To study this behaviour, we conduct a survey and confront farmers with a hypothetical opportunity to invest in a biogas plant. Our findings reveal that farmers have heterogeneous investment thresholds. Their investment decisions are mainly driven by capital costs and the subjective perception of the risk resulting from the investment. Other decision parameters like sustainability and non-monetary objectives that are also examined in this paper, play only minor roles. However, bounded rationality is an important factor. Moreover, the influence of an investment subsidy was analysed. Only about half of the amount of the subsidy - as expected according to normative forecast models - is reflected in an increased willingness to invest. Furthermore, farmers who have previously invested in bioenergy plants show lower investment thresholds and have stronger reactions to the subsidy. Regarding the expansion of renewable energies these findings are meaningful for policy impact analysis.
\end{abstract}

\section{Keywords}

Sustainability, bioenergy, policy impact analysis, investment behaviour, bounded rationality, survey analysis 
To achieve a climate-friendly energy supply in Germany in the long term, the expansion of renewable energies is seen as essential (BMU and BMELV, 2009). This expansion could be supported by a change in economic and political conditions. The recently amended German Renewable Energy Act (ErneuerbareEnergien-Gesetz, EEG), for instance, promotes the generation of electricity from renewable energy sources. Among other things, the EEG is intended to encourage investments in renewable energy systems that generate energy from biomass (BMU and BMELV, 2009). In particular, it fixes the rates that network operators must pay for electricity from renewable sources over a 20-year period ( $\$ 16 E E G$ ). The additional costs for the production of this electricity are paid by the customers. For the investor, this leads to a reduction of risk exposure on the revenue side.

It has been observed that farmers respond very differently to these incentives. Some farmers have invested in biogas plants, while others have not invested. This might be caused by farm-specific benefit and cost effects that are associated with the investment in a biogas plant. For example, the production of biogas requires the additional cultivation of energy crops, in many cases maize. This might have differing economic effects and should be seen in the context of the existing cultivation of maize and changes regarding crop rotation. However, it may also be the case that farmers make suboptimal decisions due to incomplete information and limited cognitive abilities in processing information, a phenomenon Simon (1956) refers to as 'bounded rationality' (see also Kahneman, 2003; Gigerenzer and Selten, 2001 or Selten, 1990). Frör (2008) used the concept of bounded rationality regarding environmental valuation. According to this concept, decision makers may come to different results even if they have the same entrepreneurial objectives and face identical business conditions. Bounded rationality does not refer to any deviation from the goal of profit maximisation, but rather to inconsistency in the decisionmaking behaviour. To estimate the consequences of the aforementioned economic incentives promoting bioenergy production, it is important to understand the decision-making behaviour of farmers including the impact of bounded rationality.

Thus far, a number of studies have examined the general decision-making behaviour of farmers (see, e.g., Berger, 2001; Edwards-Jones, 2006; Ilbery, 1978 or Willock et al., 1999). Furthermore, several authors have analysed the economics of biogas plants (see, e.g., Gebrezgabher et al., 2010; Heissenhuber and Berenz, 2006; Keymer, 2009 or Wulf et al. 2006), the (spatial) diffusion of biogas plants (see, e.g., Madlener and Schmid, 2008; Markard et al., 2008 or Negro and Hekkert, 2008) 
as well as the production of agricultural raw materials for these plants (see, e.g., Karpenstein-Machan, 2005). To the best of our knowledge, there is no quantitative study of the decision-making behaviour of farmers in the context of investments in biogas plants. For that reason, no models are known that explain the characteristics of different implementations of bioenergy investments. Moreover, predictions of the effects arising from changes in political surrounding conditions have been limited.

The aim of this paper is to contribute to the understanding of the decision-making behaviour of farmers in the context of investments in bioenergy. To this end, we have conducted a survey in which farm managers were interviewed and confronted with a hypothetical investment in a specific biogas plant. The necessary substratum for the biogas plant would be cultivated on land that is currently used for wheat production. To our knowledge, we are the first discussing the following questions:

1. Which conversion threshold - measured as (critical) wheat price - is necessary to motivate the respondent to invest in the biogas plant and change the existing production program?

2. What are the driving factors that influence this conversion threshold (i.e., individual risk attitude, valuation of sustainability effects, etc.)? To what extent can the observed decision-making behaviour of farmers be attributed to bounded rationality?

3. Could the expansion of bioenergy be reasonably promoted by an investment subsidy? How is this subsidy appreciated by the farmers in terms of their investment decision?

4. Is there a difference in the observed decision-making behaviour of farmers with prior experience with investments in bioenergy compared to farmers not familiar with this kind of investment?

The paper proceeds as follows: In Section 2, the design of the survey and the methodology are described in detail. Section 3 presents the results of the survey analysis for the outcome of the investment threshold of the hypothetical investment and its potential influencing factors. The explanatory power of the influencing factors is determined and the effect of an investment subsidy on the investment behaviour is illustrated. Subsequently, the result for the observed decision-making behaviour of farmers who have prior experience with investments in bioenergy is compared to that of farmers not familiar with this investment area. The article ends with conclusions (Section 4). 


\section{$2 \quad$ Data and Methods}

\subsection{Research Design}

An understanding of the decision-making behaviour of farmers is essential to adequately predict the effects arising from political changes with respect to investment conditions. The observation of farmers' real decisions is of little use in this context. On a farm, investment decisions related to a capital-intensive object (such as a biogas plant) are relatively rare. Moreover, basic conditions differ among farms (e.g., the financial resources). So it is hardly possible to draw comparisons (Gardebroek and Oude Lansink, 2008).

For these reasons, we confronted farmers with a hypothetical situation. Farmers were to decide on the implementation of a hypothetical investment. We used this type of standardised experiment to make the surrounding conditions and activities manageable (Just and Wu, 2009 as well as Roe and Just, 2009 or Starmer, 1999). Furthermore, we gave all respondents the same information to focus our analysis on the conversion threshold and on certain driving factors as well as to examine limited cognitive abilities in processing information as one part of bounded rationality. The economic experiment is designed in a manner that allows us to calculate a normative benchmark to which the empirical data can be compared.

The research is based on a survey that was mainly conducted in northwest Germany in summer 2009. It is known that farmers often share machinery, meet at special events such as agricultural trade fairs and exhibitions, exchange their views and ideas, or are members of the same farmers' association where information about biogas plants is shared. Nonetheless, we think that the interviewed farmers are mainly independent from each other: First, interviewers in different regions are used. Second, interviewed farmers are from the German federal states of Brandenburg, Hessen, Lower Saxony, North Rhine-Westphalia, Saxony, Saxony-Anhalt, Schleswig-Holstein and Thuringia. Third, the distance between the respective farms is about $500 \mathrm{~km}$ in the north-south as well as east-west direction.

Over 30 interviewers were trained, and an interview guide was provided in order to ensure uniform interview conditions. Furthermore, a quota system was applied to select the farmers. At least one-third of the interviewed persons were selected to have experience in the context of biogas plants. One hundred sixty-three German farm managers were interviewed personally. From the questionnaires, one outlier was identified (box plots, single linkage method) and eliminated. Furthermore, 27 of the resulting questionnaires were incomplete and could not be used for the analysis. 
Forty-six (34\%) of the remaining 135 farmers operate a biogas plant (hereafter referred to as 'investors'). The remaining 89 (66\%) farmers (hereafter called 'noninvestors') are not familiar with this investment area.

Table 1 provides an overview of farm and socio-demographic data. Of the 135 farms, $93 \%$ are farmed on a regular basis, and the other $7 \%$ are farmed on a part time basis. This is well above the averages in Germany, where $45 \%$ are farmed on a regular basis (BMELV, 2010). Farm size ranges from 10 ha to 2,300 ha with an average farm size of 179 ha (standard deviation: 255 ha). Investors manage on average bigger farms (231 ha; standard deviation: $357 \mathrm{ha}$ ) than the non-investors (153 ha; standard deviation: 180 ha). To give a standard of comparison, in Germany, the average farm size was 49 ha in 2007 (BMELV, 2010). Hence, the investigated farms in general and the sample of the investors in particular are above-average. The agricultural comparative figure has a range of 20 to 92 points - according to the German soil quality classification scheme from zero (worst quality) to 100 points (best quality) - and is 45 points on average (standard deviation: 18 points). Regarding the average agricultural comparative figure of the investors (42 points; standard deviation: 17 points) it roughly corresponds to the non-investors (46 points; standard deviation: 18 points). The farm managers are aged between 23 and 75 years with an average age of 46 years (standard deviation: 11 years) and $23 \%$ hold a university degree in agricultural sciences.

\section{Table 1}

Average of farm and socio-demographic data for Germany as well as for the total sample $(n=135)$, investors $(n=46)$ and non-investors $(n=89)^{a}$.

\begin{tabular}{|c|c|c|c|c|}
\hline & Germany & $\begin{array}{c}\text { Total } \\
\text { sample }\end{array}$ & $\begin{array}{c}\text { Sample } \\
\text { investors }\end{array}$ & $\begin{array}{l}\text { Sample non- } \\
\text { investors }\end{array}$ \\
\hline $\begin{array}{l}\text { Farms farmed on a } \\
\text { regular basis }\end{array}$ & $45 \%{ }^{b}$ & $93 \%$ & $96 \%$ & $92 \%$ \\
\hline sideline basis & $55 \%{ }^{b}$ & $7 \%$ & $4 \%$ & $8 \%$ \\
\hline Farm size (in ha) & $49^{b}$ & $179(255)$ & $231(357)$ & $153(180)$ \\
\hline $\begin{array}{l}\text { Agricultural comparative } \\
\text { figure (in points) }\end{array}$ & n.a. & $45(18)$ & $42(17)$ & $46(18)$ \\
\hline Age of farmer (in years) & n.a. & $46(11)$ & $46(11)$ & $46(12)$ \\
\hline
\end{tabular}

The hypothetical decision situation was as follows: Each respondent was asked to imagine managing a 200 ha crop farm. They were also asked to assume that they possessed $600,000 €$ of capital. Two investment alternatives were available. The 
money could be placed in a bank for 20 years and earn $5 \%$ interest per year or invested in a biogas plant that was recently built beside their farm. The farmers were to choose between these two alternatives.

For simplicity reasons, we have offered only one type of biogas plant as investment object to the interviewed farmers. This plant should be realistic and realisable without delivery of substratum by third parties. We have chosen a capacity of $150 \mathrm{~kW}$ as the EEG uses this kind of plant as basic model.

Therefore the biogas plant has a capacity of $150 \mathrm{~kW}$ of installed electric power. The operating expected life of the plant is 20 years and there is no residual value. Furthermore, it is assumed that the investment is tax neutral. The expected annual cash inflow is $200,000 €$ and results from the generation of power and heat. The expected cash outflow for labour costs, maintenance, electricity and insurance amounts to $100,000 €$ annually. This amount does not include the cost of the substratum. Thus, in each of the 20 years of use, the biogas plant provides an expected net cash flow of $100,000 €$ before the cost of the substratum.

Often manure and animal excrements are used as a basic substratum. These, however, have only low energy content and are often available at low cost (even no cost). For clarity reasons, the costs of manure and animal excrements were not taken into account. Over $90 \%$ of the biogas plants operating in Germany use further substrata (FNR, 2006). These are mainly energy crops. Due to its high biomass production mostly maize is used as substratum (FNR, 2006). In this case, the substratum accounts for approximately $50 \%$ of the total annual cost of a biogas plant (Walla and Schneeberger, 2008). It should be noted that the EEG promotes energy crops with an additional bonus. For the above mentioned biogas plant it is assumed that silo maize is the only substratum that can be used. The operation of the plant would require an input of $30,000 \mathrm{dt}$ (one tenth of a metric ton) of maize each year. The maize would be produced on land that is currently used to cultivate wheat. We used wheat as the competing product because it is a very common crop and its production is widely spread in Germany. So it is often replaced by the cultivation of energy crops and therefore causes opportunity costs. For farmers, the price of wheat is a kind of 'universal currency' and well known by the investors and non-investors. For this reason, our study focuses on the price of wheat.

To decouple the critical wheat price - the price below which the farmer would choose to invest in the biogas plant - from a site-specific yield level, a fixed relationship between the yield of maize and wheat is assumed: The production of $6 \mathrm{dt}$ maize replaces $1 \mathrm{dt}$ of wheat. Therefore, the wheat price is independent of the site- 
specific yield level because the wheat production on the farm must be reduced by $5,000 \mathrm{dt}$ per year. The variable costs of maize production are assumed to equal the variable costs of wheat production. The resulting digestate - the final product of the digestion process - is an 'item in transit' because the value of the fertiliser is supposed to correspond exactly to the costs of its application.

We are aware of the hypothetical character of the described situation. However, care has been taken to achieve plausible conditions. Real-world values were taken from the literature (e.g., FNR, 2006; Keymer, 2009; KTBL, 2009) and modified for simplicity of calculations. Furthermore, experts and practitioners provided feedback. Table 2 summarises the cash flows associated with the investment but was not shown to the surveyed farmers.

Table 2

Cash flow structure of the considered biogas plant (in $T €)^{a}$.

\begin{tabular}{lcccc}
\hline Period & $\mathbf{0}$ & $\mathbf{1}$ & $\mathbf{2}$ & $\mathbf{2 0}$ \\
\hline Cash inflow for: \\
Generation of power and heat \\
Cash outflow for: \\
$\begin{array}{l}\text { Investment costs } \\
\text { Others (maintenance, power etc.) }\end{array}$ \\
$\begin{array}{l}\text { Opportunity costs (lost revenues from } \\
\text { selling the 5,000 dt wheat) }\end{array}$ \\
$\begin{array}{l}\text { The variable costs of the production of wheat and maize are assumed to be equal. The value of the resulting } \\
\text { digestate (fertiliser) is supposed to correspond exactly to the costs of its application. These amounts are } \\
\text { therefore not included. }\end{array}$
\end{tabular}

After the biogas plant was described to the farmer he/she was asked for his/her investment threshold. This 'trigger price' should be defined as the average (critical) wheat price (in $€ / d t$ ) over the operating life of the plant below which the farmer would choose to invest in the above-mentioned biogas plant. Moreover the existing production program needs to be changed to secure the substratum supply of the plant. Therefore, the wheat price needs to decrease until the biogas plant is selected as the investment alternative. The trigger price reflects the subjective value that the decision maker expects from the investment.

Further questions should examine the trigger price more closely and provide information about factors that are expected to affect the price (see Section 2.2.). These 'influencing factors' consider the individual preferences of the farmer. The following questions were asked: 
1. Imagine you do not invest in the biogas plant but rather place the $600,000 €$ with a bank, earning interest of $5 \%$ annually. Please estimate the annuity that you could withdraw over a 20-year period given that the total amount is consumed at the end.

2. What is the maximum annual insurance premium that you would pay to have a guaranteed yearly incremental cash flow of $100,000 €$ generated by the biogas plant?

3. At which wheat price would you start to invest if the necessary cultivation of maize for the biogas plant had no impact on soil fertility?

4. At which wheat price would you start to invest if the biogas plant generated no environmental effects?

5. Suppose that the government would support your investment in the biogas plant with an investment subsidy of $100,000 €$. At what price of wheat would you then invest?

The first question was asked to determine the cost of capital, the second for the risk premium, the third for the soil fertility premium, the fourth for the environmental premium, and the fifth for the impact of the investment subsidy. Various pre-tests showed that to query the trigger price as well as the wheat prices in questions 3 to 5 , it is favourable to use an arrow with predetermined intervals as graphic representation and ask the farmers to mark the appropriate place with a cross. This reduces the barrier to answer the question and so the quit rate. While answering the questions, any aids (like calculators or spreadsheet applications) could be used and there were no restrictions on time. Moreover, it was possible to return the questionnaire a bit later.

\subsection{Determination of a Normative Benchmark}

The questionnaire design is based on literature-research as well as on several expert interviews. According to our knowledge, this is an original design. Nevertheless, the parts analysed are related to existing literature. We basically use the classical net present value approach and extend it by different premiums (see below). After the first draft of the questionnaire has been prepared, several pre-tests were conducted to strengthen the practical relevance and improving quality.

Can the investment behaviour of farmers be adequately explained by calculations based on rational choice models? To analyse this issue, normative benchmarks are first determined. Based on the assumptions that decision makers act perfectly rational and that profit maximisation is the only entrepreneurial objective, the net 
present value $(N P V)$ of a biogas plant with homogenous investment returns per period can be calculated as follows (cf. Brealey et al., 2008: chapter 2):

$N P V=-a_{0}+(e-a) \cdot C F_{i ; N}$,

$$
\text { with } a=q^{W} \cdot p^{W}+a^{o S} \text { and } C F_{i ; N}=\frac{(1+i)^{N}-1}{(1+i)^{N} \cdot i}
$$

$a_{0}$ denotes the investment costs, $e$ is the cash inflow and $a$ is the cash outflow. The cash outflow is composed of the costs for the substrate and other cash outflows $a^{o S}$. The cost for the substrate corresponds to the displaced wheat yield $q^{W}$ multiplied by the wheat price $p^{W}$. The interest rate is denoted by $i$, the expected useful life of the biogas plant is described by $N$ and the capitalisation factor is $C F_{i ; N}$.

The wheat price triggering the investment is the price for the crop displaced by the substrate cultivation. This price can be calculated by letting the NPV equal to zero and solving equation (1) for the wheat price $p^{W}$ :

$p^{W}=\frac{e-a^{o S}-a_{0} / C F_{i ; N}}{q^{W}}$

Therefore, the biogas plant considered in this article requires a reduction in wheat production by $5,000 \mathrm{dt}$ and investment costs of $600,000 €$, whereas it generates expected investment returns of $100,000 €$ p.a. Therefore, the corresponding wheat price is:

$p^{W}=\frac{200,000-100,000-600,000 / 12.46}{5,000}=\frac{51,854}{5,000}=10.37$

The opportunity costs for the land, which amount to $51,854 €$ p.a., pertain to the lost $5,000 \mathrm{dt}$ of wheat. With an assumed wheat price of $10.37 € / \mathrm{dt}$, the biogas plant investment results in a net present value of zero. In other words, the annual cash inflow of $20 € / \mathrm{dt}$ of wheat $(=(200,000 €-100,000 €) / 5,000 \mathrm{dt})$ allows the cost of the substratum to be $10.37 € / \mathrm{dt}$. The remaining $9.63 € / \mathrm{dt}$ is needed to cover the investment costs.

In addition to the costs of capital $(\mathrm{CoC})$ and the annual investment returns from the investment in a biogas plant that are incorporated by equation (2), other cost components may influence decision making. It has often been pointed out that entrepreneurial decisions in general and investment decisions in particular are dependent on the decision maker's risk attitude (cf. Bard and Barry, 2000 or Harwood et. al, 1999, for example). The cost component 'risk premium' $(R P)$ is influenced by the subjective perception of the risk resulting from the investment as well as the individual risk attitude of the farmer. Some farmers may frame their 
subjective perception of investment risk in terms of the supply of the substrate (the variability of silage maize yield) or the amount of the energy output (technical default risk of the biogas plant). However, other farmers may view risk in terms of the risk reduction created by diversification effects from the new branch of farm business. The larger the stated value of the risk premium, the bigger the reduction in capital expenditure will be.

Furthermore, effects concerning soil and environment (cf. Willms et al., 2009 or Muradian et al., 2010 for example) may be relevant for the evaluation of an investment in a bioenergy plant. The cost component 'soil fertility premium' $(S P)$ is determined by sustainability aspects that are relevant for soil as production factor. For instance, the decision maker may fear negative effects due to the introduced (expanded) cultivation of maize because the productivity of his land may decrease in the long term due to negative effects on crop production (e.g., potential soil erosion). The cost component 'environmental premium' $(E P)$ is relevant when decision makers have non-economic aims that are affected by the investment in a biogas plant. For example, the appreciation of climate-friendly energy production arising from the biogas plant, from the farmer's point of view, may be reflected in a negative environmental premium. In contrast, if negative environmental effects such as the ploughing-up of grassland are expected, a positive environment premium would be indicated. This leads to the following extension of equation (2):

$p^{W}=\frac{e-a^{o S}-a_{0} / C F_{i ; N}-R P-S P-E P}{q^{W}}$

Equation (4) makes clear that as the critical wheat price decreases, so the investment reluctance increases as well; the higher the risk, the higher the soil and environmental premiums.

Beside these premiums, other possible factors may increase investment reluctance. For example, the expectation of inflation or of a possible farm succession. Such factors were not considered in this investigation. Fig. 1 provides an overview of the three different normative benchmarks. 


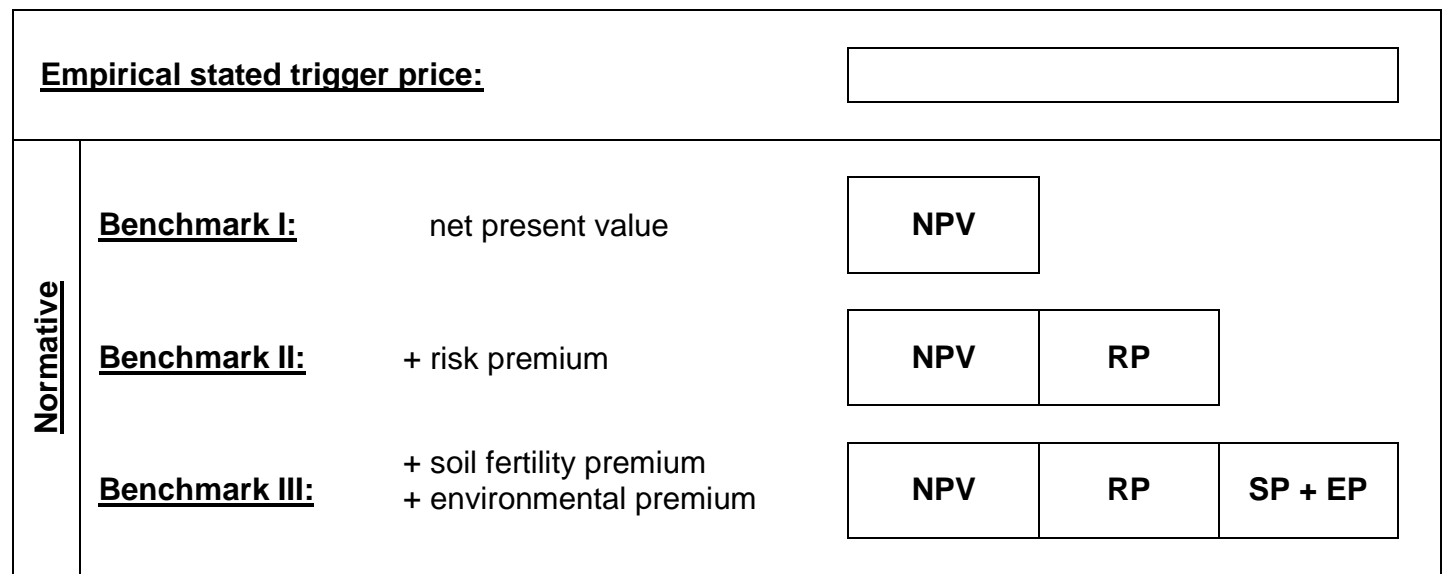

Fig. 1. Three different normative benchmarks to analyse the trigger price.

Even though it is not taken into account by equation (4), it is evident that an investment subsidy would reduce the investment costs, resulting normatively in a higher trigger price and a higher willingness to invest. Technically, the existing investment costs $a_{0}$ are replaced by $a_{0}^{\prime}=a_{0}-z$, where $z$ denotes the investment subsidy.

\section{Empirical Results and Discussion}

Section 3.1 presents the results for the trigger price and the influencing factors. In Section 3.2, the explanatory power of the influencing factors is examined using a regression model. Section 3.3 shows the effect of an investment subsidy on the investment behaviour. In Section 3.4, the results of investors and non-investors are compared. For clarity reasons, all data were converted into $€ / \mathrm{dt}$ wheat.

\subsection{Descriptive Statistics}

The survey results show that farmers have various conversion thresholds for potential investments in bioenergy production. The conversion thresholds for our example range from 5 to $30 € / \mathrm{dt}$ of wheat (see Fig. 2), even though the farmers were confronted with the same investment scenario and site-specific conditions had no effect on the critical wheat price. This indicates that the farmers' behaviour regarding potential investments in a biogas plant is very heterogeneous. Fig. 3 presents a chart of the historical wheat price from 2005 to 2010 as a standard of comparison. With regard to the historical prices, at a price of $5 € / \mathrm{dt}$ the (hypothetical) investment had never been favourable because the market price had always been higher. In contrast, the farmers that quoted a trigger price of $30 € / \mathrm{dt}$ should have invested under the assumed conditions because the market price was always lower. Overall, the range of empirical results seems plausible. 


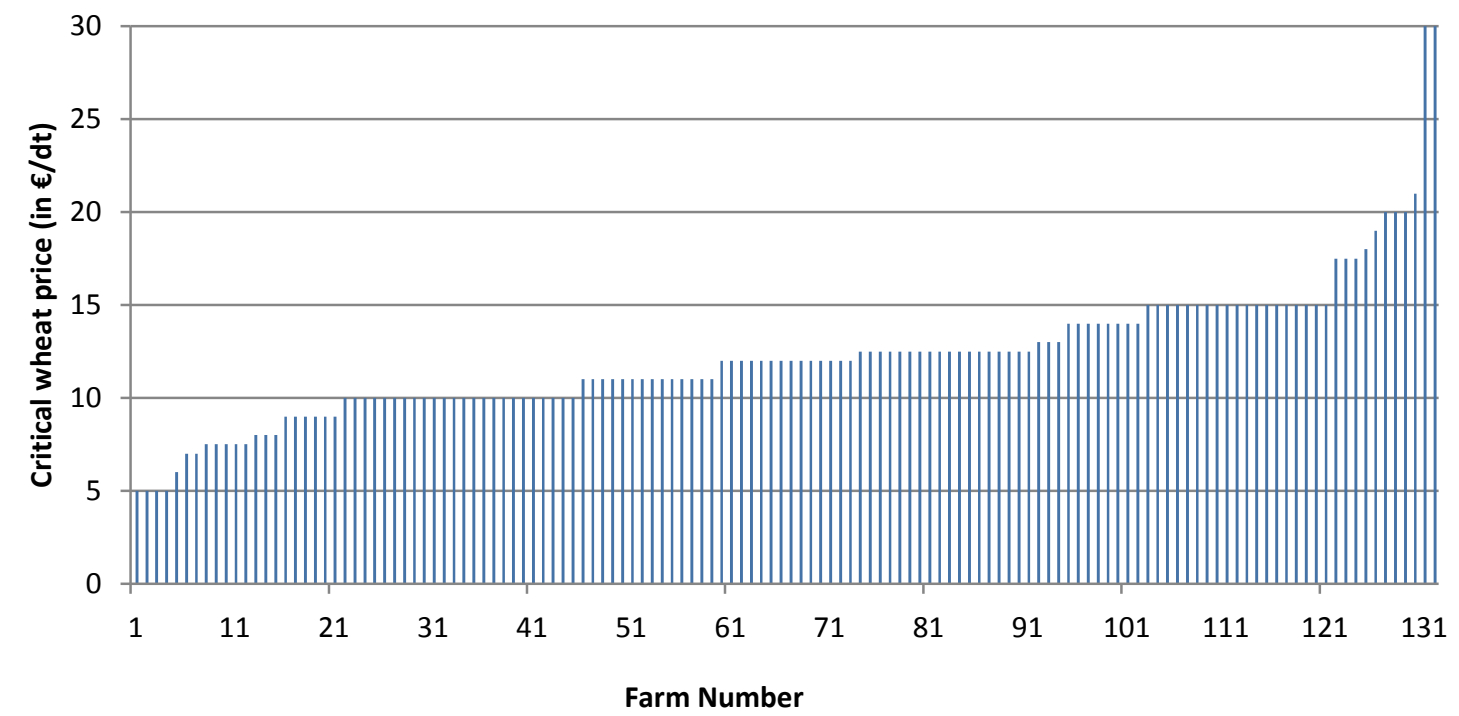

Fig. 2. Critical wheat price $(n=135$; in $€ / d t)$.

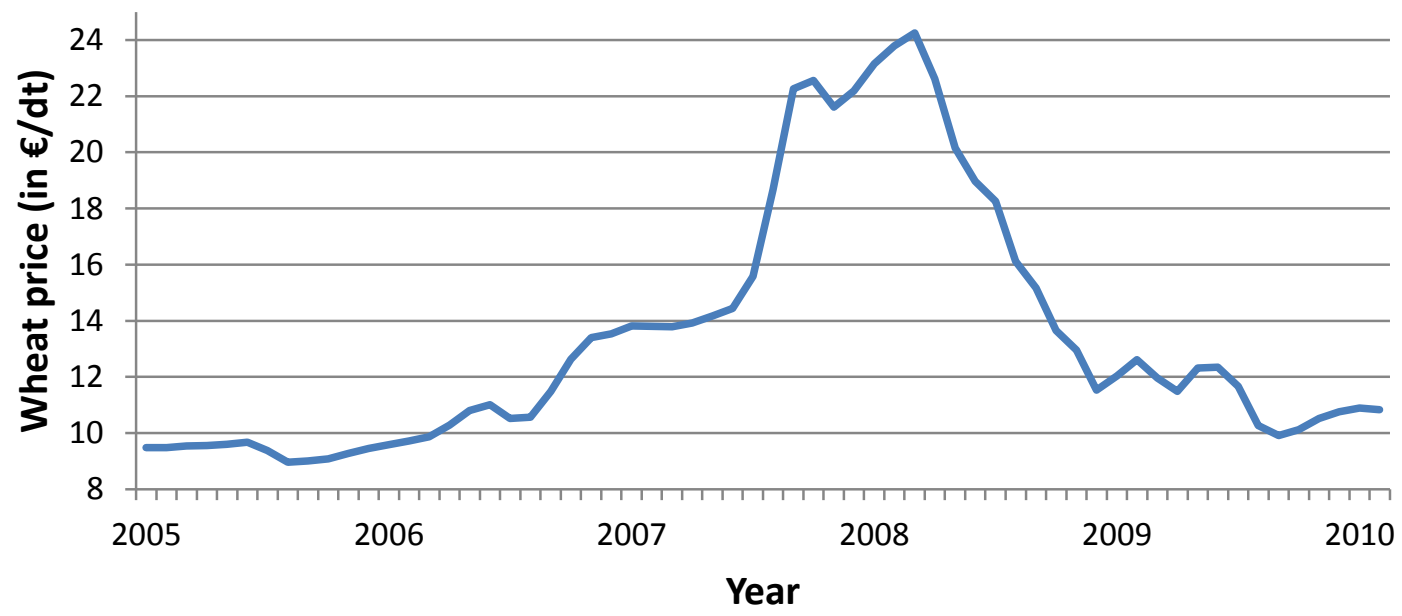

Fig. 3. Historical price chart for wheat from 2005 to 2010 (data based on GJAE, different volumes).

Table 3 shows the mean, standard deviation, minimum and maximum values for the trigger price and the influencing factors. 
Table 3

Survey results of trigger price and influencing factors $(n=135 \text {; in } € / d t)^{a}$.

\begin{tabular}{lcccccc}
\hline & $\begin{array}{c}\text { Trigger } \\
\text { price }\end{array}$ & \multicolumn{5}{c}{ Influencing factors } \\
\cline { 3 - 7 } (wheat) & $\begin{array}{c}\text { Cost of } \\
\text { capital }\end{array}$ & $\begin{array}{c}\text { Risk } \\
\text { premium }\end{array}$ & $\begin{array}{c}\text { Soil } \\
\text { fertility } \\
\text { premium }\end{array}$ & $\begin{array}{c}\text { Environmen- } \\
\text { tal premium }\end{array}$ & Others \\
\hline Mean & 12.14 & 11.86 & 1.12 & 0.19 & -0.04 & -0.99 \\
Standard & 3.78 & 2.64 & 1.05 & 1.00 & 1.20 & 4.68 \\
deviation & 5.00 & 5.00 & 0.05 & -5.00 & -7.00 & -11.00 \\
Minimum & 30.00 & 19.70 & 5.00 & 5.00 & 5.00 & 16.20 \\
Maximum & & & & & & \\
\hline
\end{tabular}

Assuming a pure profit-maximising decision maker, the normative critical wheat price is $10.37 € / \mathrm{dt}$. From the cash inflow of $20 € / \mathrm{dt}, 9.63 € / \mathrm{dt}$ remain to cover the cost of capital.

The average critical wheat price stated by the farmers is $12.14 € / \mathrm{dt}$ (standard deviation: $3.78 € / \mathrm{dt}$ ). If the farmers are myopic profit maximisers, they invest too early because the normative critical wheat price is $10.37 € / \mathrm{dt}$ (see equation (3)). This significant difference ( $p$-value $<0.001$; two-sided $t$-test) of $1.77 € / d t$ (=12.14 $€ / \mathrm{dt}-10.37 € / \mathrm{dt})$ implies a net present value of the investment in the hypothetical biogas plant of $-110,235 €$ (see equation (1)). This highly negative figure is caused by the 20-year operating life of the plant and the yearly amount of $5,000 \mathrm{dt}$ of wheat equivalent. This would seem to cast doubt on the assumption that the farmers are profit maximisers. It is important, however, to note that these results only show that the decision-making behaviour of the farmers does not correspond with equation (1). It cannot be concluded that they act under bounded rationality regarding investment decisions in the context of biogas plants. It may be that the farmers expect correspondingly large benefits from the investment arising from potential positive effects on the risk profile of the farm. In the same manner, the soil fertility premium and environmental premium could be relevant.

Hence the effects of risk, environmental and soil fertility need to be analysed in addition to the potential existence of bounded rationality. The actual cost of capital of the investment amount to $9.63 € / \mathrm{dt}$. As the farmers estimate cost of capital of $11.86 € / \mathrm{dt}$ on average, they misjudge the value by $2.23 € / \mathrm{dt}$. This difference between the empirically-measured and the normatively-determined cost of capital deviates significantly from zero ( $p$-value $<0.001$; two-sided $t$-test). It must be pointed out that this amount of $2.23 € / d$ results in a net present value of $-138.954 €$. Taking into account the correctly estimated cost of capital, the net present value of a myopic profit maximiser would c.p. total $28,719 €(=-110,235 €+138,954 €)$. The underestimation of the cost of capital could, for example, be due to a lack of skills on the part of the decision makers to adequately take into account interest and 
compound interest effects. Gigerenzer (2002) emphasises that many people have difficulty to correctly interpret relative values such as percentage values due to 'number blindness'. Musshoff and Hirschauer (2011) show that farmers underestimate interest and compound interest effects. When considered in isolation, this underestimation leads to an over-investment in bioenergy.

The average of the risk premium is about $1.12 € / \mathrm{dt}$. The positive risk premium indicates a reduction in the willingness to invest compared to a simple profit orientation. Farmers seem to be risk-averse and expect an increase in the overall corporate risk resulting from the investment in the biogas plant. Therefore, they invest later. For about $11 \%$ of the interviewed farmers, soil fertility effects are relevant and they reveal an average soil fertility premium of $0.19 € / \mathrm{dt}$. Environmental effects, which are important to approximately $12 \%$ of the farmers, result in a mean environmental premium of $-0.04 € / \mathrm{dt}$. Referring to this the negative premium shows a slightly positive perception of the investment. Just over $10 \%$ of the farmers specify a soil and environmental premium. This could be explained by the farmers' beliefs that they are already following procedure in these areas and therefore have little room to improve, even without investing in a biogas plant.

If the trigger price specified by the farmers is taken as a basis, an overall effect can be inferred. The total of the influencing factors is $13.13 € / \mathrm{dt}$ and therefore $0.99 € / \mathrm{dt}$ higher than the trigger price of $12.14 € / \mathrm{dt}$. This deviation differs significantly from zero $(p$-value $=0.016$; two-sided t-test). Therefore, the investment behaviour of the interviewed farmers cannot be appropriately described by equation (4). Furthermore, the difference of $-0.99 € / \mathrm{dt}$ could have three possible causes:

1. Bounded rationality in the context of the determination of the cost of capital, which has already been confirmed

2. Bounded rationality regarding the aggregation of the separate influencing factors and

3. Additional influencing factors that were not explicitly addressed in the interviews (e.g., effects that include ethical or image considerations)

The aforementioned difference of $-0.99 € / \mathrm{dt}$ is overcompensated by $1.24 € / \mathrm{dt}$ when the underestimated cost of capital $(2.23 € / \mathrm{dt})$ is taken into account. The residual value of $1.24 € / \mathrm{dt}$ (see Table 4) is likely divided between the two other causes mentioned above. 
Table 4

Aggregation of the influencing factors based on the empirical and normative cost of capital ( $n=135$; in $€ / d t)$.

\begin{tabular}{lcccccc}
\hline & $\begin{array}{c}\text { Trigger } \\
\text { price } \\
\text { (wheat) }\end{array}$ & \multicolumn{5}{c}{ Influencing factors } \\
\cline { 3 - 7 } & $\begin{array}{c}\text { Cost of } \\
\text { capital }\end{array}$ & $\begin{array}{c}\text { Risk } \\
\text { premium }\end{array}$ & $\begin{array}{c}\text { Soil } \\
\text { fertility } \\
\text { premium }\end{array}$ & $\begin{array}{c}\text { Environ- } \\
\text { mental } \\
\text { premium }\end{array}$ & Others \\
\hline $\begin{array}{l}\text { Mean with } \\
\text { empirical cost of capital }\end{array}$ & 12.14 & $\mathbf{1 1 . 8 6}$ & 1.12 & 0.19 & -0.04 & -0.99 \\
$\begin{array}{l}\text { Mean with } \\
\text { normative cost of capital }\end{array}$ & 12.14 & $\mathbf{9 . 6 3}$ & 1.12 & 0.19 & -0.04 & 1.24 \\
\hline
\end{tabular}

With regard to the interpretation of the results, it is important to bear in mind that decision makers in the real world - where real money is involved - have higher incentives to make optimal decisions. Therefore, real-life decisions are often based on detailed assessments, with the involvement of consultants if necessary. In the hypothetical decision situation, the incentives could not be set as if farmers were acting in a corresponding real decision situation. The impact of the bounded rationality may therefore have been overestimated. The literature emphasises, however, that effects found in non-incentive scheme experiments are in principle preserved even if the incentives are increased. With regard to bounded rationality, Schoemaker (1982: $553 \mathrm{f}$.) concludes: "[There is] no evidence that suboptimal laboratory behavior improves when committing subjects financially to their decisions" (see also Frey and Eichenberger, 1989 or Layard, 2005).

To investigate how a change in incentives affects the extent of bounded rationality in the decision situation, we integrated the aforementioned questions in a written university examination regarding investments. Fifty-nine 'prospective (farm) managers' - students of agriculture and economics in their 4th to 6th term participated (without incomplete responses). The educational requirements to capitalise are thereby ensured. However, practical experience running a business was low. The cost of capital was evaluated accurately by 25 students. However, the remaining 34 students were not able to answer the question correctly. The average cost of capital as calculated by the students is $10.08 € / \mathrm{dt}$. Compared to the normative benchmark $(9.63 € / d t)$, the students underestimated the costs of capital by about $0.45 € / \mathrm{dt}$ on average. In contrast, the farmers' absolute deviation from the normative benchmark is $2.23 € / \mathrm{dt}$. Therefore, the level of bounded rationality regarding the cost of capital decreases with the larger incentive but is not totally eliminated. 


\subsection{Explanatory Power of the Potential Influencing Factors}

The hypothetical decision-making situation might have been too abstract for the farmers or they could not understand the decision-making situation. Therefore, we analyse whether there are significant correlations between the trigger price of the described biogas plant and the potential influencing factors. Based on a multiple linear regression analysis, we examine the extent to which the influencing factors affect the trigger price:

$y_{i}=\sum_{j=1}^{J} a_{j} \cdot x_{i j}+\varepsilon_{i}, \quad$ with $i=1,2, \ldots, I$

$y_{i}$ denotes the dependent variable (trigger price) of the $i$-th observation (questionnaire) and $a_{j}$ is the corresponding regression coefficient for the $j$-th independent variable $x_{i j}$ (influencing factor: $C o C, R P, S P$ or $E P$ ). $\varepsilon_{i}$ is the error term of the regression. The regression coefficients $a_{j}$ are estimated by the ordinary least squares method. Table 5 shows the results of the regression ${ }^{1}$.

Table 5

Results of the multiple linear regression with the trigger price as dependent variable and the influencing factors as independent variables $(n=135)$.

\begin{tabular}{|c|c|c|c|c|}
\hline & $\begin{array}{l}\text { Cost of } \\
\text { capital }\end{array}$ & $\begin{array}{c}\text { Risk } \\
\text { premium }\end{array}$ & $\begin{array}{c}\text { Soil } \\
\text { fertility } \\
\text { premium }\end{array}$ & $\begin{array}{l}\text { Environmen- } \\
\text { tal premium }\end{array}$ \\
\hline Regression coefficients & 0.909 & 0.923 & -0.322 & -0.083 \\
\hline $\begin{array}{l}\text { Standardised regression } \\
\text { coefficients }\end{array}$ & 0.869 & 0.112 & -0.026 & -0.008 \\
\hline $\begin{array}{l}\text { t-value } \\
\text { (p-value) }\end{array}$ & $\begin{array}{l}22.041 \\
(0.000)\end{array}$ & $\begin{array}{c}2.838 \\
(0.005)\end{array}$ & $\begin{array}{l}-0.889 \\
(0.375)\end{array}$ & $\begin{array}{l}-0.272 \\
(0.784)\end{array}$ \\
\hline $\mathrm{R}^{2}\left(\right.$ adjusted $\left.\mathrm{R}^{2}\right)$ & \multicolumn{4}{|c|}{$0.895(0.892)$} \\
\hline F-value ( $p$-value) & \multicolumn{4}{|c|}{$279.722(0.000)$} \\
\hline
\end{tabular}

The coefficient of determination $R^{2}$ is 0.895 (adjusted $R^{2}=0.892$ ); it therefore presents a high explanatory potential. About $89 \%$ of the variation in the trigger price can be explained by the four regressors. Furthermore, the $\mathrm{F}$ statistic for the proposed regression model indicates high significance $(F-$ value $=279.722$ and $p$-value $<0.001)$. Thus, the coefficient of determination and the $F$ statistic as global quality

\footnotetext{
${ }^{1}$ Following a reviewer's advice selected test results are briefly mentioned: There is no multicollinearity apparent for the independent variables (result of tolerance test: CoC 0.515 ; RP 0.517; EP 0.981; SP 0.952). The normality assumption for the distribution of the error terms seems reasonable (result of Kolmogorov-Smirnov test: $p$-value $=0.498$ ).
} 
criterions demonstrate that the regression model is not misspecified. They indicate that the farmers' answers are not based on pure guesswork and that the farmers properly understand the complex hypothetical decision-making situation.

In addition to the overall explanatory potential of the influencing factors, each influencing factor's input is of particular interest. The significance of each regression parameter is analysed using a t-test. The cost of capital ( $t$-value $=22.041$ and $p$ value $<0.001$ ) and the risk premium ( $\mathrm{t}$-value $=2.838$ and $\mathrm{p}$-value $=0.005$ ) influence the trigger price significantly at a probability of error of less than $1 \%$. The impacts of the soil fertility premium ( $t$-value $=-0.889$ and $p$-value $=0.375$ ) and the environmental premium ( $\mathrm{t}$-value $=-0.272$ and $\mathrm{p}$-value $=0.784$ ), however, are not significant. The standardised regression coefficients show that cost of capital $(0.869)$ followed by the risk premium (0.112) offers the highest explanatory potential for the investment behaviour concerning bioenergy plants. In contrast, the standardised regression coefficients of the soil fertility premium $(-0.026)$ and the environmental premium (0.008 ) have only little influence.

A separate regression analysis with bounded rationality in the context of cost of capital as a determinant (see Section 3.1) was conducted. But personal characteristics such as age or level of education as independent variables showed no significance.

\subsection{Impacts of the Investment Subsidies}

Specific bioenergy policies are designed to increase the production of energy from renewable resources. How can the willingness of farmers to invest in bioenergy plants be increased? Bearing in mind the net present value (see equation (4)), there are three main possibilities. In addition to the reduction of the risk of the investment returns $(e)$, which is guaranteed by the EEG, a low-interest credit $(i)$ can lead to a decreased need for capital spending caused by the interest advantage. A further alternative to create investment incentives is the lowering of investment costs $\left(a_{0}\right)$ through a subsidy $(z)$.

As an example, we investigate the third possibility. We therefore asked the farmers to state their trigger price under the assumption of an investment subsidy of $100,000 €$ for the biogas plant mentioned above. In consideration of the subsidy, the reduced investment costs amount to $500,000 €$. From a macroeconomic point of view, subsidies might help to support the adoption of new technologies in the initial stages of market diffusion by making such technology relatively less expensive. But a support program of investments may also cause a misallocation of resources 
(Brümmer and Loy, 2000); however, these aspects are not considered in the present article.

Under the assumption of perfect rationality and profit maximisation as the only entrepreneurial objective and under the abstraction of application costs for the promotion, according to equation (2), the reduced investment costs lead to an increase in the trigger price by $1.60 € / \mathrm{dt}$. In other words, as expected, the investment should be carried out earlier, c.p. The subsidy would have a positive impact in the case that the average critical wheat price stated by the farmers of $12.14 € / \mathrm{dt}$ rises to more than $13.74 € / \mathrm{dt}$ with all else equal.

Table 6 presents the means, standard deviations and ranges of the trigger price before and after the implementation of the investment subsidy.

Table 6

Consequences of the investment subsidy $(n=135 \text {; in } € / d t)^{a}$.

\begin{tabular}{lcccccc}
\hline & $\begin{array}{c}\text { Trigger price } \\
\text { before subsidy }\end{array}$ & \multicolumn{2}{c}{$\begin{array}{c}\text { Trigger price } \\
\text { after subsidy }\end{array}$} & \multicolumn{2}{c}{$\begin{array}{c}\text { Changes in } \\
\text { propensity to invest }\end{array}$} & $\begin{array}{c}\text { Empirically } \\
\text { unanticipated } \\
\text { part of subsidy }\end{array}$ \\
\cline { 2 - 5 } & empirical & expected & empirical & expected & empirical & part \\
\hline Mean & 12.14 & 13.74 & 13.03 & 1.60 & 0.89 & 0.71 \\
$\begin{array}{l}\text { Standard } \\
\text { deviation }\end{array}$ & 3.78 & - & 3.73 & - & 2.17 & 2.17 \\
Minimum & 5.00 & - & 2.00 & - & -7.50 & -4.90 \\
Maximum & 30.00 & - & 29.00 & - & 6.50 & 9.10 \\
\hline
\end{tabular}

a The amount of the investment subsidy is $100,000 €$.

The range of the empirical trigger price has changed slightly from 2 to $29 € / \mathrm{dt}$ with the investment subsidy compared to 5 to $30 € / \mathrm{dt}$ without the investment subsidy. Therefore, the minimum and maximum trigger prices have not shifted in the expected direction. Due to the investment subsidy, the average critical wheat price increases from $12.14 € / \mathrm{dt}$ to $13.03 € / \mathrm{dt}$. Therefore, on average, farmers' willingness to invest is increased by the subsidy as expected. In particular, 83 of the 135 farmers stated a higher trigger price, 30 were not affected by the subsidy and 22 farmers stated a lower trigger price. The net present value of the average price, however, would be $-65,692 €$ if the wheat price were $13.03 € / \mathrm{dt}$ (without the subsidy: $-110,235 €)$. Thus, the net present value would increase by about $45,000 €$ due to the investment subsidy of $100,000 €$.

Although the normative expected change in the trigger price is $1.60 € / \mathrm{dt}$, only $0.89 € / \mathrm{dt}$ of that amount is reflected in an increase in the average willingness to invest. The remaining $0.71 € / \mathrm{dt}$ do not have the expected effect. Hence, about $45 \%$ 
of the investment subsidy is not reflected in an increase in the willingness to invest. Based on a comparison of means, the anticipated and the unanticipated part of the subsidy differ significantly from zero ( $p$-value $<0.001$; two-sided $t$-test). We could exaggerate and say that in the case of the considered investment decision, the investment subsidy would have to be approximately $200,000 €$ to effect an incentive of $100,000 €$.

The results may have two explanations. First, some farmers may expect a high effort due to bureaucracy and work (including the disutility of labour during desk work) caused by the investment subsidy. As a consequence, even if a subsidy is offered, the willingness to invest would not increase to the same extent as expected according to normative forecast model, or it may even decrease. This should be anticipated in the way farmers are informed and recruited to biogas investments. Second, the bounded rationality of the decision makers may mean that they do not understand the actual value of an investment subsidy.

\subsection{Effects of Prior Experience with Investments in Bioenergy}

In this section, the analysis of the total population of the interviewed farmers will be augmented by a comparison of means between bioenergy investors and noninvestors in this area. Table 7 shows the means for the trigger price and the influencing factors before the subsidy for the two groups as well as for the trigger price after the subsidy was offered.

Table 7

Comparison of means of the investors $(n=46)$ and non-investors $(n=89)$ concerning trigger price and influencing factors (in $€ / d t$ ) as well as investment subsidy.

\begin{tabular}{|c|c|c|c|c|c|c|c|c|}
\hline & \multirow{3}{*}{$\begin{array}{l}\text { Trigger } \\
\text { price } \\
\text { before } \\
\text { subsidy }\end{array}$} & \multicolumn{5}{|c|}{ Influencing factors before subsidy } & \multirow{2}{*}{\multicolumn{2}{|c|}{$\begin{array}{l}\text { Trigger price } \\
\text { after subsidy }^{\mathrm{a}}\end{array}$}} \\
\hline & & \multirow{2}{*}{$\begin{array}{l}\text { Cost of } \\
\text { capital }\end{array}$} & \multirow{2}{*}{$\begin{array}{c}\text { Risk } \\
\text { premium }\end{array}$} & \multirow{2}{*}{$\begin{array}{c}\text { Soil } \\
\text { fertility } \\
\text { premium }\end{array}$} & \multirow{2}{*}{$\begin{array}{c}\text { Environ- } \\
\text { mental } \\
\text { premium }\end{array}$} & \multirow[t]{2}{*}{ Others } & & \\
\hline & & & & & & & $\begin{array}{c}\text { ex- } \\
\text { pected }\end{array}$ & $\begin{array}{c}\text { em- } \\
\text { pirical }\end{array}$ \\
\hline Investors & 13.11 & 11.77 & 1.35 & 0.21 & -0.09 & -0.13 & 14.71 & 14.26 \\
\hline $\begin{array}{l}\text { Non- } \\
\text { investors }\end{array}$ & 11.64 & 11.91 & 1.01 & 0.17 & -0.02 & -1.43 & 13.24 & 12.40 \\
\hline $\begin{array}{l}\text { Difference } \\
\text { (p-value) }\end{array}$ & $\begin{array}{c}1.47 \\
(0.032)\end{array}$ & $\begin{array}{c}-0.14 \\
(0.780)\end{array}$ & $\begin{array}{c}0.34 \\
(0.074)\end{array}$ & $\begin{array}{c}0.04 \\
(0.860)\end{array}$ & $\begin{array}{c}-0.07 \\
(0.749)\end{array}$ & $\begin{array}{c}1.30 \\
(0.122)\end{array}$ & - & $\begin{array}{c}1.86 \\
(0.006)\end{array}$ \\
\hline
\end{tabular}

a The amount of the investment subsidy is $100,000 €$.

The aforementioned average trigger price of the total population rises from $12.14 € / \mathrm{dt}$ (see Table 3 ) to $13.11 € / \mathrm{dt}$ for the investors. In contrast, the non-investors stated an average trigger price of $11.64 € / \mathrm{dt}$. Therefore, they would invest consider- 
ably later. The difference of $1.47 € / \mathrm{dt}$ is significant ( $p$-value $=0.032$; two-sided t-test). Thus, the results are in accordance with the real investment decisions of the respective group.

Furthermore, the analysis of the influencing factors shows different premiums for the influencing factors of the two groups. For cost of capital ( $p$-value $=0.780$; two-sided t-test), soil fertility premium ( $p$-value $=0.860$; two-sided $t$-test) and environmental premium ( $p$-value $=0.749$; two-sided t-test) these differences are not significant. In contrast, the risk premium is significant at the $10 \%$-level. The non-investors valued the risk premium at $1.01 € / \mathrm{dt}$ and the investors quoted it about $34 \%$ higher, at $1.35 € / \mathrm{dt}$. Based on their prior experience with biogas production, this larger amount might reflect the evaluation of the (specific) investment alternative assuming a comparable risk aversion by the farmers in both groups.

Even though the position 'others' is not significant on a $10 \%$ level, it has to be noted that the p-value of 0.122 (two-sided t-test) is by far better than for the cost of capital, the soil fertility premium and the environmental premium. The average amount of the investors $(-0.13 € / d t)$ is - in absolute terms - considerably smaller than the $-1.43 € / \mathrm{dt}$ of the non-investors. The practical knowledge of their prior bioenergy investment in particular might lead to the more consistent evaluation. However, this difference could also demonstrate the non-investors' reluctance that is due to ethical aspects that put bioenergy on a level with 'combustion of grain' and therefore give it a substantial negative value. For future research it would be interesting to find out if ethical issues are a significant factor for the non-investors.

Table 7 shows the impact of the investment subsidy separated for the two groups. From the normative point of view, the $1.60 € / \mathrm{dt}$ of the subsidy is expected to result in an average trigger price after subsidy of $14.71 € / \mathrm{dt}$ for the investors and $13.24 € / \mathrm{dt}$ for the non-investors. However, the investors stated a trigger price of $14.26 € / \mathrm{dt}$ after subsidy. Therefore, they changed their propensity to invest by $1.15 € / \mathrm{dt}$. In contrast, the trigger price after subsidy of the non-investors was $12.40 € / \mathrm{dt}-\mathrm{a}$ change of $0.76 € / \mathrm{dt}$ in the propensity to invest.

This means that $72 \%$ and $48 \%$ of the amount of the subsidy are perceived by investors and non-investors, respectively, and that the first group responds much stronger than the second group. So farmers who have already adopted biogas technology respond more positively to further investments in this technology. This implies that there are barriers to adoption and diffusion of this technology. However, this might be partially due to deadweight effects. Hence, many of the investments would be carried out even without the subsidy, and the relevant target group is not 
reached. Furthermore, the results indicate that the subsidy examined here could lead to a concentration of biogas plants in regions where farmers have already invested heavily.

\section{Conclusions}

In the context of a sustainable energy supply and for policy impact analysis, it is important to understand the (different) development of investments in biogas plants at the farm level to make adequate predictions of effects arising from changes in surrounding conditions. In this paper, the decision-making behaviour of farmers in the context of these investments is investigated. As part of a questionnaire, farm managers were confronted with a hypothetical decision situation regarding an investment in a biogas plant. The survey results confirm that farmers have various conversion thresholds for potential investments in bioenergy (trigger prices below which the farmers would choose to invest in a biogas plant; in addition the existing production program needs to be changed to secure the substratum supply of the plant). This explains why they respond very differently to economic conditions. Moreover, farmers who have invested in a biogas plant in reality also invest earlier in the experiment than the other farmers.

Furthermore, the answers of the farmers are compared to three types of normative benchmarks, which contain different components to isolate the driving factors that influence the conversion threshold. The first benchmark only contains the cost of capital. A risk component is added for the second benchmark. The third benchmark is extended to include soil fertility and environmental premiums. These potential components of the trigger price show different levels of influence. The effects, which are investigated in terms of aspects of soil sustainability, the altered substrate cultivation and non-economic objectives, have a low explanatory power for the level of the trigger price. In contrast, the individual assessment of risk and the cost of capital have a high impact on the level of the trigger price. Another essential influencing factor is bounded rationality regarding the evaluation of the cost of capital; the capital costs are often underestimated.

To determine the potential of investment incentives to promote the early adoption of this technology, the impact of an investment subsidy was analysed. On average, only about $55 \%$ of the amount was perceived by the farmers. Furthermore, farmers who had prior experience with bioenergy investments reacted much more strongly to the subsidy compared to farmers who were not familiar with this area, which could be partly based on deadweight effects. Investment subsidies are already viewed 
critically in agricultural policy and will be further called into question if this effect is confirmed by future studies.

The results show that bounded rationality has an effect on the behaviour of real decision makers and that real decision makers do not follow normative forecast models. Therefore, rational choice is not always suitable for explaining economic decision making (cf. Faucheux and Froger, 1995). This indicates two things. First, it suggests that additional profits arising from attractive but unrealised and unattractive but realised investments could be made. Second, decision-making aid in terms of training (human capacity building) could be helpful to counteract these wrong decisions. It should be noted that support for decision making is not about influencing or changing the farmer's preferences. Instead, it is about increasing the farmer's utility by reducing his/her bounded rationality and enabling him/her to make decisions that are better aligned with his/her individual preferences.

The behavioural economic aspects of bounded rationality need to be researched more deeply. This implies, for instance, collecting more detailed information regarding the farmers' socioeconomic background, such as education, age, income, and family background. It also implies investigating the decision-making process to discover the algorithms, heuristics and calculi used to make the decision. In the context of climate-related risks Helgeson et al. (2010) provide a working model of an individual formation of preferences.

On a more general level, bioenergy could be considered as being one part of a sustainable energy supply system. In contrast to wind energy or photovoltaics, bioenergy allows to store the energy and to adapt production to the demand. Although bioenergy production plays an important role and "room for innovation [is required]" (Madlener and Stagl, 2005: 162) it needs to be ensured that the use of public subsidies is effective, efficient and transparent. However, it should be noted in this regard that "[consumers] are in favor of a policy for renewable energy [... and] are willing to pay a higher price for electricity in order to internalize the external costs in terms of energy security, climate change and air pollution caused by the production of electricity" (Longo et al., 2008: 140). 


\section{Acknowledgment}

The authors would like to thank the editor, two anonymous reviewers, Dr. Oleg Nenadić and Holger Reise for their valuable comments and suggestions. We gratefully acknowledge financial support from the Ministry for Science and Culture of Lower Saxony (MWK).

\section{References}

Bard, S.K., Barry, P.J., 2000. Developing a scale for assessing risk attitudes of agricultural decision maker. International Food and Agribusiness Management Review 3 (1), 9-25.

Berger, T., 2001. Agent-based spatial models applied to agriculture: A simulation tool for technology diffusion, resource use changes and policy analysis. Agricultural Economics 25 (2-3), 245-260.

BMELV (Federal Ministry of Food, Agriculture and Consumer Protection), 2010. Ausgewählte Daten und Fakten der Agrarwirtschaft 2010, Berlin.

BMU (Federal Ministry for the Environment, Nature Conservation and Nuclear Safety), BMELV (Federal Ministry of Food, Agriculture and Consumer Protection), 2009. Nationaler Biomasseaktionsplan für Deutschland. Beitrag der Biomasse für eine nachhaltige Energieversorgung. BMU, Referat KI III 2, BMELV Referat N2.

Brealey, R.A., Myers, S.C., Allen, F., 2008. Principles of corporate finance, ninth ed. McGraw-Hill, New York.

Brümmer, B., Loy, J.-P., 2000. The technical efficiency impact of farm credit programmes: A case study of Northern Germany. Journal of Agricultural Economics 51 (3), 405-418.

Edwards-Jones, G., 2006. Modelling farmer decision-making: Concepts, progress and challenges. Animal Science 82 (6), 783-790.

Faucheux, S., Froger, G., 1995. Decision-making under environmental uncertainty. Ecological Economics 15 (1), 29-42.

FNR (Agency for Renewable Resources e.V.), 2006. Handreichung - Biogasgewinnung und-nutzung. FNR, Gülzow. 
Frey, B., Eichenberger, R., 1989. Zur Bedeutung entscheidungstheoretischer Anomalien für die Ökonomik. Jahrbücher für Nationalökonomie und Statistik 206 (2), 81-101.

Frör, O., 2008. Bounded rationality in contingent valuation: Empirical evidence using cognitive psychology. Ecological Economics 68 (1-2), 570-581.

Gardebroek, C., Oude Lansink, A.G.J.M., 2008. Dynamic microeconometric approaches to analysing agricultural policy. Paper of the 107th Seminar of the European Association of Agricultural Economists (EAAE), Sevilla, Spain.

Gebrezgabher, S.A., Meuwissen, M.P.M., Oude Lansink, A.G.J.M., 2010. Costs of producing biogas at dairy farms in The Netherlands. International Journal on Food System Dynamics 1 (1), 26-35.

Gigerenzer, G., 2002. Calculated risks: How to know when numbers deceive you. Simon \& Schuster, New York.

Gigerenzer, G., Selten, R., 2001. Bounded rationality: The adaptive toolbox. MA: MIT Press, Cambridge.

GJAE (German Journal of Agricultural Economics), different volumes. Industry data. Harwood, J., Heifner, R., Coble, K., Perry, J., Somwaru, A., 1999. Managing risk in farming: Concepts, research, and analysis. Market and Trade Economics Division and Resource Economics Division, Economic Research Service, U.S. Department of Agriculture, Agricultural Economic Report No. 774.

Heissenhuber, A., Berenz, S., 2006. Energieproduktion in landwirtschaftlichen Unternehmen, in: Darnhofer, I., Wytrzens, H.K., Walla, C. (Eds.), Alternative Strategien in der Landwirtschaft. Facultas Verlags- und Buchhandel AG, Wien, pp. 135-144.

Helgeson, J., Dietz, S., Chabay, I., 2010. Analyzing preferences over climate-related risks: Proposed mental models. Contributed paper of the 11th Biennial Conference: "Advancing Sustainability in a Time of Crisis", International Society for Ecological Economics (ISEE), Oldenburg and Bremen, Germany, available under: http://www.isee2010.org/paper/24ps0508\%23Analyzing\%20percep tions\%20of\%20climate\%20change\%20risk\%23_Helgeson,Jennifer_.pdf, 23.03.2011.

Ilbery, B.W., 1978. Agricultural decision-making: A behavioural perspective. Progress in Human Geography 2 (3), 448-466. 
Just, D.R., Wu, S.Y., 2009. Experimental economics and the economics of contracts. American Journal of Agricultural Economics 91 (5), 1382-1388.

Kahneman, D., 2003. Maps of bounded rationality: Psychology for behavioral economics. American Economic Review 93 (5), 1449-1475.

Karpenstein-Machan, M., 2005. Energiepflanzenbau für Biogasanlagenbetreiber. DLG-Verlags-GmbH, Frankfurt am Main.

Keymer, U., 2009. Rentabilität der Biogaserzeugung - Erläuterungen, Übersichten und Musterkalkulationen zum Erneuerbaren-Energien-Gesetz (EEG). Schriftenreihe des Hauptverbandes der landwirtschaftlichen Buchstellen und Sachverständigen, Heft 183. HLBS Verlag, Sankt Augustin.

KTBL (Association for Technology and Structures in Agriculture e.V.), 2009. Faustzahlen Biogas, second ed. KTBL, Darmstadt.

Layard, R., 2005. Happiness: Lessons from a new science. Penguin, New York and London.

Longo, A., Markandya, A., Petrucci, M., 2008. The internalization of externalities in the production of electricity: Willingness to pay for the attributes of a policy for renewable energy. Ecological Economics 67 (1), 140-152.

Madlener, R., Schmid, C., 2008. Spatial diffusion of biogas technology in Switzerland: A GIS-based multi-agent simulation approach. International Journal of Environment and Pollution 39 (1-2), 28-43.

Madlener, R., Stagl, S., 2005. Sustainability-guided promotion of renewable electricity generation. Ecological Economics 53 (2), 147-167.

Markard, J., Madlener, R., Schmid, C., Stadelmann, M., Umbach-Daniel, A., 2008. Biogasnutzung in der Schweiz: Hemmnisse, Förderfaktoren und zukunftsorientierte Analysen. Studie im Auftrag von novatlantis, Endbericht, Zürich.

Muradian, R., Corbera, E., Pascual, U., Kosoy, N., May, P.H., 2010. Reconciling theory and practice: An alternative conceptual framework for understanding payments for environmental services. Ecological Economics 69 (6), 12021208.

Musshoff, O., Hirschauer, N., 2011. A behavioral economic analysis of bounded rationality in farm financing decisions - First empirical evidence. Agricultural Finance Review 71 (1), 62-83. 
Negro, S., Hekkert, M., 2008. Explaining the success of emerging technologies by innovation system functioning: The case of biomass digestion in German. Technology Analysis \& Strategic Management 20 (4), 465-482.

Roe, B.E., Just, D.R., 2009. Internal and external validity in economics research: Tradeoffs between experiments, field experiments, natural experiments, and field data. American Journal of Agricultural Economics 91 (5), 1266-1271.

Schoemaker, P.J., 1982. The expected utility model: Its variants, purposes, evidence and limitations. Journal of Economic Literature 20, 529-563.

Selten, R., 1990. Bounded rationality. Journal of Institutional and Theoretical Economics 146 (4), 649-658.

Simon, H.A., 1956. Rational choice and the structure of environments. Psychological Review 63 (2), 129-138.

Starmer, C., 1999. Experimental economics: Hard science or wasteful tinkering? The Economic Journal 109 (453), F5-F15.

Walla, C., Schneeberger, W., 2008. The optimal size for biogas plants. Biomass and Bioenergy 32 (6), 551-557.

Willock J., Deary, I.J., McGregor, M.M., Sutherland, A., Edwards-Jones, G., Morgan, O., Dent, B., Grieve, R., Gibson, G., Austin, E., 1999. Farmers' attitudes, objectives, behaviors, and personality traits: The Edinburgh study of decision making on farms. Journal of Vocational Behavior 54 (1), 5-36.

Willms, M., Deumlich, D., Hufnagel, J., Reinicke, F., Wagner, B., v. Buttlar, C., 2009. Anbauverfahren für Energiepflanzen - Auswirkungen auf Boden und Umwelt, in: Fachagentur Nachwachsende Rohstoffe e.V. (Eds.), Gülzower Fachgespräche, Band 32: Tagungsband, Biogas in der Landwirtschaft - Stand und Perspektiven. Fachagentur Nachwachsende Rohstoffe e.V., Gülzow, pp. 148162.

Wulf, S., Jäger, P., Döhler, H., 2006. Balancing of greenhouse gas emissions and economic efficiency for biogas-production through anaerobic co-fermentation of slurry with organic waste. Agriculture, Ecosystems and Environment 112 (2-3), 178-185. 


\section{Untersuchung zu Verträgen für die Rohstoffversorgung von Biogasanlagen}




\section{Präferenzen von Landwirten bei der Gestaltung von Substrat- lieferverträgen für Biogasanlagen: Ein Choice-Experiment}

Farmers' preferences regarding the design of substrate supply contracts for biogas plants: A choice experiment

Christian Reise, Ulf Liebe, Oliver Mußhoff

Dieser Beitrag erscheint in German Journal of Agricultural Economics (im Druck).

\section{Zusammenfassung}

Für einen nachhaltigen Ausbau von Energie aus Biogasanlagen ist die Versorgung mit Substraten notwendig, die vielfach über entsprechende Lieferverträge geregelt wird. Nach Wissen der Autoren liegen bislang keine quantitativen Untersuchungen zur Analyse des Auswahlverhaltens von Landwirten in Bezug auf Lieferverträge für diese Anlagen vor. Daher sind Aussagen bezüglich einer zielführenden Ausgestaltung von Lieferverträgen nur eingeschränkt möglich. Wir haben deshalb im Rahmen einer Befragung von 178 deutschen Landwirten untersucht, inwieweit verschiedene Faktoren für den Abschluss von Substratlieferverträgen relevant sind. Dazu wurde ein Choice Experiment durchgeführt. Durch die systematische Variation von Vertragsmerkmalen wird der jeweilige Einfluss auf die Wahrscheinlichkeit eines Vertragsabschlusses bestimmt. Es wird deutlich, dass die befragten Landwirte Verträge mit anderen Landwirten oder einem Bioenergiedorf gegenüber außerlandwirtschaftlichen Investoren bevorzugen. Weiterhin sinkt die Wahrscheinlichkeit eines Vertragsabschlusses mit zunehmender Laufzeit. Demgegenüber wird ein Vertrag durch einen höheren Verkaufspreis für die Betriebsleiter attraktiver. Die Untersuchung der Befragtenmerkmale zeigt, dass die Höhe der Prämie für ein zusätzliches Jahr Vertragslaufzeit von der individuellen Wertschätzung der unternehmerischen Freiheit des jeweiligen Betriebsleiters abhängig ist. Es ist nicht festzustellen, dass risikoaverse Landwirte tendenziell Verträge mit festen Preisen gegenüber Verträgen mit Preisgleitklauseln bevorzugen. Zudem zeigen sich keine großen Unterschiede im Auswahlverhalten von Landwirten, die einen Substratliefervertrag abgeschlossen haben, und Landwirten ohne diese Erfahrung. 


\title{
Schlüsselwörter
}

Erneuerbare Energien; Bioenergie; Substratliefervertrag; Vertragsgestaltung; (Labeled) Choice Experiment

\begin{abstract}
Substrate supply, which is often regulated by corresponding contracts, is essential for a sustainable expansion of renewable energies generated in biogas plants. To the authors' knowledge, no quantitative investigations of farmers' selection preferences with regard to supply contracts for biogas plants have been carried out so far. Hence, it has been only possible to a limited extent to make predictions for a targeted arrangement of supply contracts. We therefore investigated, to what extent different factors have relevance for the conclusion of substrate supply contracts. This has been done by conducting a survey with 178 German farm managers. The survey included a choice experiment in which participants were confronted with different contract features. These features were varied systematically and thus revealed the influence of each individual feature on the probability of contract conclusion. It becomes clear that the farmers who were interviewed preferred to conclude contracts with other farmers or with a bioenergy village rather than with external investors. The probability of contract conclusion decreases with an increasing lifetime of the contract. However, a contract with a higher sales price is more attractive for the farmers. The investigation of the characteristics of respondents shows that the amount of the premium for one additional year of contractual lifetime depends on the individual valuation of the entrepreneurial freedom of the respective farm manager. It cannot be established that risk-averse farmers tend to prefer contracts with fixed prices over contracts with price adjustment clauses. In addition, there are no great differences in the selection behavior of farmers who have already signed a substrate supply contract and farmers without this experience.
\end{abstract}

\section{Key Words}

Renewable energy; bioenergy; substrate supply contract; contract design; (labeled) choice experiment 


\section{Einleitung}

Um langfristig eine klimaverträgliche Energieversorgung im Allgemeinen und in Deutschland im Speziellen sicherzustellen, wird ein Ausbau erneuerbarer Energien angestrebt (vgl. z.B. BMU und BMELV, 2009; ISERMEYER et al., 2008). Zukünftig sollen sich die verschiedenen Arten der dezentral erzeugten erneuerbaren Energien ergänzen. Durch dieses sogenannte virtuelle Kraftwerk (ARNDT et al., 2006) sollen die jeweiligen Nachteile - wie beispielsweise mangelnde Speicherbarkeit - einiger Methoden der Erzeugung erneuerbarer Energien über die Vorteile der anderen erneuerbaren Energien kompensiert werden. Im System einer nachhaltigen Energieversorgung kommt der Erzeugung von Biogas als „Regelenergie“ besondere Bedeutung zu. Im Gegensatz zu Windenergie oder Photovoltaik ist es bei der Erzeugung von Bioenergie möglich, die Zufuhr des notwendigen Substrates gezielt zu steuern und das entstehende Gas zu speichern (vgl. SCHRÖER, 2010; SCHAPER et al., 2011). Dadurch kann die Stromproduktion besser an die Nachfrage angepasst werden.

Für den weiteren Ausbau der Biogaserzeugung ist es von zentraler Bedeutung, dass die erforderlichen Substratmengen durch die Landwirtschaft bereitgestellt werden, um den Betrieb der Biogasanlagen zu ermöglichen. Oft ist bei größeren Anlagen und Anlagenbetreibern, denen eigenes Substrat nicht (in ausreichender Menge) zur Verfügung steht, eine Substratzulieferung durch Dritte notwendig. Dieses ist insofern von Bedeutung, als dass die Substratkosten rund die Hälfte der jährlichen Kosten einer Biogasanlage ausmachen (vgl. z.B. WALLA und SCHNEEBERGER, 2008; FNR, 2009). Deshalb ist Substratlieferverträgen als Schnittstelle zwischen Substratanbauern und Biogasanlagenbetreibern besondere Beachtung zu schenken. Somit stellt sich die Frage nach den Präferenzen der landwirtschaftlichen Betriebsleiter bei der Ausgestaltung von Substratlieferverträgen.

Es liegt eine Vielzahl an Untersuchungen zu Lieferverträgen vor. Beispielsweise untersuchen KATCHOVA und MIRANDA (2004), KEY (2004) sowie ROE et al. (2004) die Akzeptanz für Verkaufsverträge bei US-Schweineproduzenten. STEFFEN et al. (2009) befragen deutsche Milchviehhalter nach ihren Vorstellungen zur Vertragsgestaltung mit den Molkereien nach Abschaffung der Milchquote im Jahr 2015. MUBHOFF und HIRSCHAUER (2011) analysieren die Akzeptanz von Landwirten für Ethanolrübenlieferverträge.

Gegenwärtig ist Mais einer der bedeutendsten nachwachsenden Rohstoffe zur Gewinnung von Bioenergie (FNR, 2007: 94). Dies liegt vor allem daran, dass er im gemäßigten Klima Mitteleuropas sehr hohe Trockenmasseerträge liefert. Im Jahr 
2010 wurden in Deutschland 2,3 Mio. ha Mais angebaut (DMK, 2011). Allerdings liegen unseres Wissens bislang keine quantitativen Untersuchungen des Auswahlverhaltens von Landwirten in Bezug auf Maislieferverträge für Biogasanlagen vor. Somit ist es bisher nur eingeschränkt möglich, Aussagen hinsichtlich einer zielführenden Ausgestaltung von Maislieferverträgen zu treffen.

Mittels Choice Experimenten (CE) können die Präferenzen von Probanden bei Auswahlentscheidungen analysiert und die Entscheidungsrelevanz einzelner Merkmale des jeweiligen Untersuchungsgegenstandes bewertet werden. Sehr verbreitet sind CE im Bereich der Marktforschung, d.h. sie werden bei der Untersuchung von Kaufentscheidungen von Konsumenten (vgl. z.B. GREEN und SRINIVASAN, 1990) genutzt. Zudem bietet sich diese Methode für die Bewertung ökosystemarer Dienstleistungen an (vgl. z.B. ADAMOWICz et al., 1994 oder SCHMITZ et al., 2003). In BOUGHERARA und Ducos (2006) werden drei hypothetische Angebote für Vertragsnaturschutz mit Hilfe eines CE analysiert. QIN et al. (2011) nutzen ein CE bei der Beurteilung von Pachtverträgen für forstwirtschaftlich genutzte Flächen in China.

Für die Untersuchung der Präferenzen landwirtschaftlicher Betriebsleiter bei der Ausgestaltung von Substratlieferverträgen erscheinen CE aus verschiedenen Gründen als geeignet: Zumeist werden Verträge in der Praxis als „vertrauliche Interna" behandelt, so dass wenig Transparenz herrscht und somit keine ausreichende Datenbasis für z.B. eine ökonomische Analyse der Vertragsakzeptanz verfügbar ist. Zudem unterscheiden sich die Rahmenbedingungen der Betriebe untereinander, wodurch einfache Vergleiche (nicht) abgeschlossener Substratlieferverträge kaum möglich sind. Daher bietet es sich an, eine direkte Bewertungsmethode (Stated Preference Method) zu nutzen und mit hypothetischen Entscheidungssituationen zu arbeiten. Da sowohl die Handlungsmöglichkeiten als auch die Rahmenbedingungen kontrollierbar sind, kann das Auswahlverhalten besser analysiert werden, als auf der Grundlage empirischer Entscheidungen (ROE und JUST, 2009 oder JUST und WU, 2009). Entgegen einer offenen und direkten Abfrage werden Merkmale und Ausprägungen bei CE vorgegeben (vgl. QIN et al., 2011). Zudem kann die Interaktion der Merkmale berücksichtigt werden. Bei CE ist keine direkte Angabe einer Zahlungsbereitschaft erforderlich, weil diese durch die Analyse der Auswahlentscheidungen in Form impliziter Preise abgeleitet wird (SCHMITZ et al., 2003). Vorteilhaft ist zudem, dass CE über eine hohe externe Validität verfügen (vgl. z.B. AUSPURG und LIEBE, 2011) und die Durchführung gegenüber der Kontingenten 
Bewertungsmethode (Contingent Valuation Method) kostengünstiger ist (vgl. HoYOS, 2010: 1601).

Ziel dieses Beitrags ist es, aus der Perspektive von landwirtschaftlichen Betriebsleitern wesentliche Faktoren für den Abschluss von Substratlieferverträgen zur Rohstoffversorgung von Biogasanlagen aufzuzeigen und Aussagen zur Bedeutung von ausgewählten Vertragsbestandteilen abzuleiten. Wir haben deshalb landwirtschaftliche Betriebsleiter im Rahmen eines CEs mit verschiedenen Substratlieferverträgen konfrontiert. Konkret wird folgenden Fragestellungen nachgegangen:

1) „Vertragsmerkmale“: Werden von Landwirten bestimmte Vertragspartner, Vertragslaufzeiten und Preisausgestaltungen bevorzugt?

2) „Befragtenmerkmale“: Inwiefern wirkt sich die individuelle Wertschätzung von unternehmerischer Freiheit (Flexibilität) des Betriebsleiters auf die Vertragslaufzeit aus? Zeigt sich die Risikoeinstellung des Betriebsleiters in der Preisausgestaltung eines gewählten Vertrages?

3) „Erfahrungen“: Welchen Einfluss haben Erfahrungen mit Substratlieferverträgen auf das Entscheidungsverhalten der Landwirte?

Im nachfolgenden Abschnitt 2 wird der theoretische Hintergrund der Untersuchung erläutert und die zu untersuchenden Hypothesen abgeleitet. Abschnitt 3 beschreibt das Untersuchungsdesign. Dazu wird zunächst das methodische Vorgehen erläutert und dann die Ausgestaltung des CE und der Aufbau des Fragebogens beschrieben. In Abschnitt 4 wird ein Überblick über die Stichprobe und über die von den Betriebsleitern bisher abgeschlossenen Substratlieferverträge gegeben. Anschließend werden die Ergebnisse in Abschnitt 5 dargestellt. Zunächst wird über Ergebnisse zu gewünschten Vertragsmerkmalen und deren Stellenwert berichtet. Danach werden die Hypothesen auf Basis der Ergebnisse des CE überprüft. Der Beitrag endet mit Schlussfolgerungen und einem Ausblick (Abschnitt 6).

\section{Theoretischer Hintergrund und Hypothesenbildung}

Bei der ökonomischen Bewertung von Biogasanlagen werden die Substratkosten vielfach als pauschale Größe angesetzt oder unter verschiedenen Rahmenbedingungen optimiert (vgl. z.B. HeISSENHUBER und BERENZ, 2006; WULF et al., 2006; KEYMER, 2009 oder GeBREZGABHER et al., 2010). Dabei wird die Verfügbarkeit von Substrat häufig als gegeben angenommen. STÜRMER und EDER (2010) optimieren beispielsweise die Versorgung einer Biogasanlage unter Berücksichtigung der jährlichen Kosten für Anbau und Kulturführung sowie Ernte und Gülleausbringung unter Einbeziehung von Nutzungskosten der benötigten Ackerfläche. 


\section{Wahl des Vertragspartners}

Bei den von uns zu untersuchenden Fragestellungen wird davon ausgegangen, dass die Zulieferung von Substrat durch Dritte notwendig ist, d.h., dass für den Betrieb einer Biogasanlage Substrat zugekauft werden muss. Aufgrund des hohen Wasseranteils bei Silomais und der damit geringen Transportwürdigkeit (vgl. z.B. GRUBER, 2006; SCHULZE STEINMANN und HOLM-MÜLLER, 2010) kann nicht von einem großräumigen Markt ausgegangen werden. Daher kommen im Wesentlichen dezentrale Lösungen, wie regionale Partnerschaften, in Betracht (vgl. z.B. BAHRS et al., 2008).

In der Anbahnungsphase eines Vertrages sind die verfügbaren Informationen unvollständig, da weder die zukünftigen Substratpreise bekannt sind noch mit Sicherheit davon ausgegangen werden kann, dass alle Vertragspartner ihre (wahren) Präferenzen preisgeben. STEINHORST und BAHRS (2011) betonen die Bedeutung einer bewussten Auswahl von Geschäftspartnern. Im Zusammenhang mit Substratlieferverträgen kommen verschiedene Biogasanlagenbetreiber (z.B. andere Landwirte, außerlandwirtschaftliche Investoren usw.) als potenzielle Vertragspartner in Frage. Die erste Hypothese $(\mathrm{H})$ lautet wie folgt:

H 1 „Relevanz Vertragspartner“: Die Art des Vertragspartners hat Auswirkungen auf die Wahrscheinlichkeit einer Vertragsauswahl.

\section{Wertschätzung unternehmerischer Freiheit}

Viele Landwirte legen großen Wert auf ihre Unabhängigkeit. Beispielsweise untersuchen SPILLER und SCHULZE (2006) inwiefern deutsche Schweinemäster - unter dem Aspekt der motivationalen Bedeutung des freien Unternehmertums bereit sind, vertikale Bindungen einzugehen. Sie berichten von einer überwiegend skeptischen Haltung, die u.a. emotional begründet ist. Neben emotionalen Aspekten hat eine Einschränkung der unternehmerischen Freiheit auch finanzielle Auswirkungen. In MUBHOFF und HIRSCHAUER (2008) werden Lieferlizenzen für Roggen mit einem garantierten Abnahmepreis über einen definierten Lieferzeitraum untersucht. Dabei wird u.a. die Unsicherheit hinsichtlich der Spotmarktpreise für Roggen und die Möglichkeit einer Vertragsannahme zu einem späteren Zeitpunkt berücksichtigt. Bei den untersuchten Lieferlizenzen konnte gezeigt werden, dass die Verträge nur von extrem risikoaversen Landwirten sofort angenommen werden sollten. Einschränkende Vertragsmerkmale, wie beispielsweise eine lange Laufzeit, verringern die Attraktivität eines Vertrages (ROE et al., 2004). Diese können c.p. durch eine 
Autonomieprämie (vgl. z.B. KEY, 2005 oder KEY und MACDONALD, 2006) ausgeglichen werden. Die zweite Hypothese bezieht sich daher auf das Verhältnis von Flexibilität und Vertragslaufzeit:

H 2 „Flexibilität und Vertragslaufzeit": Landwirte wertschätzen unternehmerische Freiheit (Flexibilität). In Abhängigkeit der individuellen Wertschätzung fordern sie daher mit zunehmender Vertragslaufzeit eine steigende Kompensationsprämie.

\section{Bedeutung der Risikoeinstellung}

Die landwirtschaftliche Produktion ist mit Risiken verbunden (vgl. z.B. TIEDEMANN et al., 2011), die durch vertragliche Vereinbarungen reduziert werden können. Unternehmerische Entscheidungen - wie der Abschluss eines Vertrages - sollten damit von der Risikoeinstellung des Betriebsleiters abhängig sein (vgl. z.B. BARD und BARRY, 2000 oder HARWOOD et al., 1999). Man geht davon aus, dass Unternehmer in der Realität risikoavers sind, wenngleich in unterschiedlichem Maße (vgl. z.B. ANDERSEN, 2008). Risikoaverse Entscheider sind bereit, für die Reduzierung des Risikos eine Prämie zu bezahlen. Für risikoneutrale Entscheider würde das Risiko keine Rolle spielen, d.h. die geforderte Risikoprämie wäre Null.

Ein optimal abgestimmter Vertrag sollte zu einem Ausgleich der Interessen beider Vertragsparteien führen und dabei im Hinblick auf Rechte und Pflichten auch einen angemessenen Preis für die Übernahme von Risiken berücksichtigen (vgl. JANG und OLSON, 2010). Dazu kann die Ausgestaltung des Preises auf unterschiedliche Weise geregelt werden: Die Vergütung der Substrate kann in dem Liefervertrag zu einem fest vereinbarten Preis erfolgen (im Folgenden: Festpreis-Vertrag) ${ }^{2}$. Mit dieser garantierten Preissicherung wird aber auch die zukünftige Teilnahme an vorteilhaften Preisentwicklungen ausgeschlossen. ROLAND et al. (2009) diskutieren alternative Preisfestlegungen. Im Rahmen diverser Preisanpassungsklauseln wird eine Vergütung untersucht, die sich an zukünftigen Marktpreisen orientiert (im Folgenden: Marktpreis-Vertrag). Werden beispielsweise die Preise von Referenzfrüchten genutzt, können die direkten Opportunitätskosten der verdrängten Früchte berücksichtigt werden. Bei diesem Ansatz wird der Substratpreis nicht garantiert und kann bei Vertragsabschluss nur als erwartete Größe Berücksichtigung finden. Den vorgenannten Aspekten Rechnung tragend ergibt sich folgende Hypothese ${ }^{3}$ :

2 Diese Verträge können durchaus deterministische Preiszuschläge beinhalten, wie beispielsweise eine garantierte pauschale Steigerung von jährlich 1,5\%.

3 Aus Vereinfachungsgründen wird von konstanten Preiserwartungen der Teilnehmer ausgegangen. 
H 3 „Risikoeinstellung und Preisausgestaltung“: Risikoaverse (risikofreudige) Landwirte bevorzugen Festpreis-Verträge (Marktpreis-Verträge) gegenüber Marktpreis-Verträgen (Festpreis-Verträgen) bei sonst gleichen Vertragsmerkmalen. Wenn sie sich über einen Festpreis-Vertrag festlegen, ist eine geringere Prämie erforderlich als bei risikofreudigen Landwirten.

\section{Erfahrungen mit Substratlieferverträgen}

Erfahrungen entstehen durch ein Lernen aus konkreten Problemstellungen (vgl. CAMERON, 1999). Jedoch können vorhandene Erfahrungen nur eingeschränkt auf andere Situationen übertragen werden (vgl. LOEWENSTEIN, 1999). Personen entwickeln sich durch zusätzliche Erfahrungen weiter (vgl. CHEUNG und FRIEDMAN, 1998). Beispielsweise können Landwirte, die über Erfahrungen hinsichtlich der Investition in eine Biogasanlage verfügen, den Wert einer Investitionszulage besser einschätzen als Landwirte ohne diese Erfahrung (vgl. REISE et al., 2012). Die abschließende Hypothese zu Substratlieferverträgen baut auf diese Erkenntnisse auf:

H 4 „Erfahrungen“: Landwirte, die über Erfahrungen durch abgeschlossene Substratlieferverträge verfügen, zeigen Unterschiede im Auswahlverhalten von Verträgen verglichen mit Landwirten ohne diese Erfahrungen.

\section{Untersuchungsdesign}

\subsection{Methodisches Vorgehen}

Reale Wirtschaftssubjekte verfolgen in aller Regel Mehrfachziele, die neben einer individuellen Berücksichtigung von Risikoaspekten auch internalisierte Wertvorstellungen und nicht-monetäre Motivationen (z.B. Tradition oder soziale Anerkennung) beinhalten können (vgl. z.B. SCHWARTZ, 1994; BENZ, 2006). Zudem verhalten sie sich zumindest teilweise begrenzt rational (vgl. z.B. SIMON, 1956; SELTEN, 1990; GIGERENZER, 2002; ReISE et al., 2012). Deshalb besteht die Gefahr, dass bei Rational-Choice-Ansätzen, die von reiner Gewinnmaximierung ausgehen, Art und Geschwindigkeit des Anpassungsverhaltens an veränderte Rahmenbedingungen falsch eingeschätzt werden. Der Einsatz experimenteller Ansätze stellt eine Alternative dar. Hierzu zählen neben Laborexperimenten auch Befragungsstudien mit hypothetischen Entscheidungssituationen, wie z.B. CE (vgl. z.B. WossINK und VAN WENUM, 2003). CE stellen eine Erweiterung der klassischen Conjoint-Analyse dar (vgl. ScHMiTZ et al., 2003; zu einem Vergleich der beiden Methoden siehe 
ENNEKING, 2003). Für die Conjoint-Analyse (consider jointly) werden „die Einzelmerkmale zusammenhängend betrachtet, indem möglichst realistische Produktalternativen zur Entscheidung vorgelegt werden, die systematisch in ihren Ausprägungen variieren“ (ENNEKING, 2003: 255).

Bei CE - einer Kombination aus Befragung und Experiment - entscheiden sich die Teilnehmer für eine der zur Auswahl stehenden (Handlungs-)Alternativen, ähnlich der Auswahlentscheidung eines Konsumenten (HOYOS, 2010: 1595; für weiterführende Literatur siehe beispielsweise LOUVIERE et al., 2000 oder HENSHER et al., 2005). Den Teilnehmern wird dazu ein sogenanntes Choice-Set mit verschiedenen (Handlungs-)Alternativen vorgelegt und um Auswahl gebeten. Häufig wird diese Wahlentscheidung mit weiteren Choice-Sets wiederholt. In diesen Choice-Sets werden die zu untersuchenden Merkmale systematisch variiert, um den jeweiligen Einfluss auf die Auswahlentscheidung festzustellen (vgl. z.B. LOUVIERE et al., 2000; LIST et al., 2006). Damit kann der jeweilige Nutzenbeitrag der Merkmale und Ausprägungen zu dem Gesamtnutzen („Nutzen-Bündel“) bestimmt werden.

\subsection{Ausgestaltung des CE und Aufbau des Fragebogens}

\section{Auswahl von Merkmalen und deren Ausprägungen}

Reale Verträge berücksichtigen eine Vielzahl an gegenläufigen Interessen (vgl. BOGETOFT und OLESEN, 2002). Dieses schlägt sich häufig in umfangreichen Regelungen nieder. Für die Überprüfung der Hypothesen wurden bei der Ausgestaltung des CE abschlussrelevante „Hauptvertragsmerkmale“ berücksichtigt. Die Auswahl der Merkmale und deren Ausprägungen basiert auf einer Literaturrecherche, der Analyse von Praxis- und Musterverträgen und Expertengesprächen. Die drei Hauptmerkmale „Vertragspartner“, „Vertragslaufzeit“ und „Verkaufspreis“ werden nachfolgend kurz dargestellt.

ROE et al. (2004) betonen die Bedeutung der Organisationsform des Vertragspartners. Daher werden in der vorliegenden Untersuchung verschiedene Vertragspartner zur Auswahl gestellt. Bei der Analyse von Praxisverträgen haben wir die folgenden Vertragspartner-Klassen als relevant identifiziert: Landwirte, Bioenergiedorf und außerlandwirtschaftlicher Investor (vgl. Tabelle 1). Eine finanzielle Beteiligung an einer (gemeinschaftlichen) Biogasanlage wird nicht von jedem Landwirt gewünscht. Unabhängig von dieser Beteiligung besteht jedoch vielfach die Möglichkeit, sich über Substratlieferverträge an der Rohstoffversorgung einer Biogasanlage von anderen Landwirten zu beteiligen. Zudem kann die Substratversorgung eines Bioenergiedorfes unterstützt werden. Nach RUPPERT et al. (2008:10) wird „in einem 
Bioenergiedorf ... das Ziel verfolgt, möglichst die gesamte Wärme- und Stromversorgung eines Ortes auf Basis des erneuerbaren Energieträgers „Biomasse“ zu stellen und die Bioenergieanlagen in Eigenregie zu betreiben“. Außerdem sind in der Praxis Substratlieferverträge für Anlagen zu finden, die von außerlandwirtschaftlichen Investoren (z.B. Energieversorgungsunternehmen) betrieben werden.

ROE et al. (2004) berichten, dass eine lange Vertragslaufzeit die Attraktivität eines Vertrages verringert und diese durch eine höhere Vergütung ausgeglichen werden kann. Wir wollen dieses im Zusammenhang bei Substratlieferverträgen untersuchen und bieten dazu den Befragungsteilnehmern unterschiedlich lange Vertragslaufzeiten an: 1 Jahr, 5 Jahre und 9 Jahre.

Bei größeren Biogasanlagen wird der Preis häufig von dem Substratkäufer vorgegeben. Diese "Gegenpartei“ würde den Preis im Allgemeinen möglichst niedrig ansetzen und abwarten, ob Verträge über eine ausreichende Liefermenge abgeschlossen würden. Andernfalls würden der Substratpreis oder andere Vertragsmerkmale angepasst werden (vgl. z.B. JANG und OLSON 2010). MUBHOFF und HIRSCHAUER (2011) haben Landwirte im Zusammenhang mit Lieferverträgen für Ethanolrüben befragt und herausgefunden, dass die Nachbesserung eines Vertrages, die nach dem erfolglosen ersten Vertragsangebot vorgenommen wird, eine geringere Akzeptanz bewirkt als ein sofortiges höheres Vertragsangebot. Doch welcher Preis wird von den Landwirten akzeptiert?

Bei nachfolgender Untersuchung soll zwischen Verträgen zu Festpreisen und Verträgen zu Marktpreisen unterschieden werden. Erfolgt eine Vergütung zu Festpreisen, so wird der Preis über die gesamte Vertragslaufzeit mit Sicherheit vom Vertragspartner garantiert. Demgegenüber ist bei einer Vergütung zu Marktpreisen nur das Ausgangspreisniveau bzw. - keinen Trend vorausgesetzt - der erwartete (Durchschnitts-)Preis bekannt. Der Preis wird somit nicht garantiert. Die Verkaufspreise werden im CE jeweils als Silomaispreis und ergänzend als Weizenpreisäquivalent angegeben. Diese zusätzliche Angabe erfolgt, da der Anbau von Weizen in Deutschland sehr verbreitet ist und diese Leitkultur auch von Betriebsleitern gut eingeschätzt werden kann, die über keine Erfahrung mit dem Anbau von Mais verfügen. Es wird angenommen, dass durch die Erzeugung von $6 \mathrm{t}$ Mais ein Ertrag von $1 \mathrm{t}$ Weizen verdrängt wird. Um möglichst realistische Bedingungen zu schaffen, wurden die angesetzten Substratpreise aus der Literatur entnommen (vgl. z.B. FNR, 2007; KEYMER, 2009; KTBL, 2009; GeBreZGABHER et al., 2010): 20, 30 und $40 € / t$ Silomais. 
Für eine realitätsnahe Gestaltung der Merkmale und Ausprägungen wurden zudem Pre-Tests und weitere Expertengespräche durchgeführt.

Tabelle 1. Merkmale und Ausprägungen der Vertragsangebote im CE

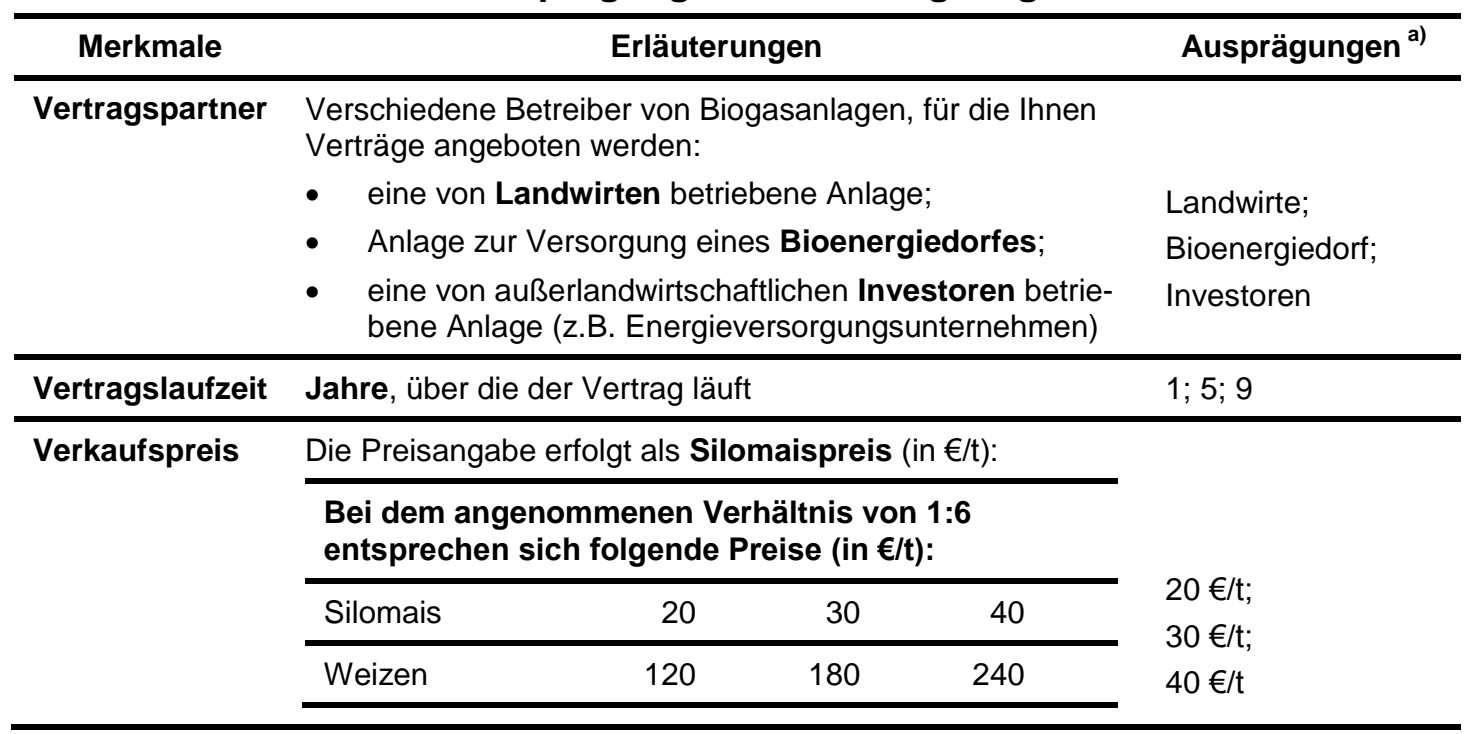

a) Die Verträge können zu Fest- oder Marktpreisen abgeschlossen werden. Bei einer Vergütung zu Festpreisen wird der Preis über die gesamte Vertragslaufzeit mit Sicherheit garantiert. Im Gegensatz zum Festpreis kann dieser bei einer Vergütung zu Marktpreisen nicht garantiert werden. Daher erfolgt hier die Angabe als erwarteter Preis.

Quelle: eigene Darstellung

\section{Design der Choice-Sets}

Zur Bestimmung der jeweiligen Einflussstärke auf die Auswahlentscheidung werden die Vertragskomponenten systematisch variiert. Das experimentelle Design ist die Kombination von Merkmalen und Ausprägungen (vgl. Tabelle 1) für die Ausgestaltung der Alternativen in den Choice-Sets (HoYOS, 2010: 1596). Da ein volles faktorielles (full factorial) Design, die Menge aller möglichen Choice-Sets, zu umfangreich ist, $u m$ es von den Befragten bewerten $\mathrm{zu}$ lassen $\left[\left(3^{*} 3^{*} 3\right)_{\text {Festpreis-Vertrag }}{ }^{*}\left(3^{*} 3^{*} 3\right)_{\text {Marktpreis-Vertrag }}=729\right.$ Kombinationen $]$ (HENSHER et al., 2005: 112; LOUVIERE et al., 2000: 84ff.), wurde ein sogenanntes fraktionalisiertes (fractional factorial) Design erstellt. Als Optimalitätskriterium wurde ein „optimal orthogonal in the differenced (OOD) design" (vgl. z.B. BURGESS und STREET, 2005) gewählt. Das Design optimiert auf Orthogonalität aller Haupteffekte der Merkmale hin. Damit lässt sich der Effekt eines jeden Merkmals auf die Auswahlwahrscheinlichkeit eines Vertrages unabhängig von den anderen Merkmalen schätzen. Darüber hinaus sollen maximale Unterschiede zwischen den Merkmalsausprägungen in einem Choice-Set erzielt werden. Dies bedeutet, dass es in einem Choice-Set so wenig wie möglich gleiche Ausprägungen pro Merkmal gibt. Im vorliegenden Fall 
sind 9 Choice-Sets notwendig, um diese Anforderungen optimal sicherzustellen (maximale D-Optimalität von 100\%). Allen zu befragenden Probanden werden die vollen 9 Choice-Sets in zufälliger Abfolge vorgelegt (keine Aufteilung in Blöcke). Abbildung 1 zeigt beispielhaft eines dieser Choice-Sets. Da die Teilnehmer zwischen einem Festpreis-Vertrag und einem Marktpreis-Vertrag wählen können, handelt es sich um ein sogenanntes labeled CE. Zudem wird eine Opt-outAlternative angeboten, bei der die Möglichkeit besteht, sich für keinen der genannten Verträge zu entscheiden.

\section{Abbildung 1. Beispielhaftes Choice-Set}

\begin{tabular}{|l|l|l|}
\hline & FESTPREIS-VERTRAG & MARKTPREIS-VERTRAG \\
\hline Vertragspartner & Bioenergiedorf & Landwirte \\
\hline Vertragslaufzeit & 1 Jahr & 5 Jahre \\
\hline Verkaufspreis: & garantiert & erwartet \\
Silomais & $20 € / \mathrm{t}$ & \\
(entspricht Weizen) & $(120 € / \mathrm{t})$ & \multicolumn{2}{|c|}{$(180 € / \mathrm{t}$} \\
\hline $\begin{array}{l}\text { Ich wähle ... } \\
\text { (Bitte anklicken) }\end{array}$ & $\mathrm{O}$ & \multicolumn{2}{|c|}{$\mathrm{O}$} \\
\hline
\end{tabular}

Quelle: eigene Darstellung

keinen der beiden

\section{Aufbau des Fragebogens}

Der entwickelte Fragebogen besteht aus drei Teilen. Im ersten Teil „Ihre Einschätzung zu potenziellen Substratlieferverträgen“ wird mit dem CE begonnen, um einen Einfluss der anderen Fragebogenteile auf das Antwortverhalten auszuschließen. Im Rahmen des CEs werden die Teilnehmer - aus Gründen der Vergleichbarkeit gebeten, sich in die Lage zu versetzen, einen Ackerbaubetrieb mit 100 ha Fläche zu bewirtschaften. Für die Substratversorgung einer neu gebauten Biogasanlage in der Nähe des jeweiligen Betriebes, werden den Befragten zwei alternative Substratlieferverträge für Silomais angeboten. Die Teilnehmer können hierbei zwischen einem Festpreis-Vertrag und einem Marktpreis-Vertrag auswählen. Die Verträge unterscheiden sich in den vorgenannten Ausprägungen der Merkmale „Vertragspartner“, „Vertragslaufzeit“ und „Verkaufspreis“ (vgl. Tabelle 1). Im zweiten Teil des Fragebogens wird u.a. ein Fokus auf unternehmerische Freiheit und die Risikoeinstellung der landwirtschaftlichen Unternehmer gerichtet. Zudem wird Fragestellungen hinsichtlich des Energiepflanzenanbaus und zu potenziell abgeschlossenen 
Substratlieferverträgen nachgegangen. Im dritten Teil werden Informationen zu den Betrieben und den Betriebsleitern erhoben.

\section{Deskriptive Auswertungen}

Im Sommer 2011 wurde die „Befragung landwirtschaftlicher Betriebsleiter zu Substratlieferverträgen mit Biogasanlagenbetreibern“" webbasiert durchgeführt. Die Akquise der landwirtschaftlichen Betriebsleiter wurde durch Interessenverbände, universitäre Alumni-Netzwerke und Studierende der Agrarwissenschaften unterstützt. Insgesamt haben 178 landwirtschaftliche Betriebsleiter den Fragebogen bearbeitet. Nachfolgend werden nähere Angaben zu den befragten Betrieben bzw. den teilnehmenden landwirtschaftlichen Betriebsleitern gemacht und ein Überblick über die abgeschlossenen Substratlieferverträge gegeben.

\subsection{Betriebsstrukturelle und sozioökonomische Charakteristika}

Einen Überblick zu den betriebsstrukturellen und soziodemographischen Charakteristika ist in Tabelle 2 zu finden. Von den teilnehmenden Betrieben werden 86,0\% im Haupt- und 14,0\% im Nebenerwerb geführt. Der bundesdeutsche Durchschnitt für den Haupterwerb ist geringer und liegt bei 45,0\% (BMELV, 2010: 8). Fast die Hälfte der Stichprobe besteht aus Ackerbaubetrieben. Ein weiteres Viertel sind Gemischtbetriebe und ein Fünftel Veredlungsbetriebe. Die von den Betrieben bewirtschaftete Fläche reicht von 7 bis 5.000 ha und beträgt im Mittel 283,3 ha. Im Vergleich zum bundesdeutschen Durchschnitt von 48,5 ha (BMELV, 2010: 3) sind die befragten Betriebe überdurchschnittlich groß. Die mittlere Zahl der Bodenpunkte liegt in der Stichprobe bei 53,4 Punkten.

Von den Teilnehmern hat rund die Hälfte ein landwirtschaftliches Studium absolviert. Der Anteil weiblicher Landwirte, die an der Befragung teilgenommen haben, beträgt 4,1\%. Das Alter der Betriebsleiter liegt zwischen 19,0 und 73,0 Jahren und im Mittel bei 43,1 Jahren. Zudem misst der Großteil der Landwirte ihrer unternehmerischen Freiheit (Flexibilität) große Bedeutung zu: Auf einer 5er-Skala mit 1 (trifft überhaupt nicht zu) bis 5 (trifft voll und ganz zu) wurde im Durchschnitt ein Wert von 4,2 ausgewählt. In Anlehnung an die Selbsteinschätzung der Risikoeinstellung des Sozio-oekonomischen Panels (SOEP) des Deutschen Instituts für Wirtschaftsforschung (DIW) (DOHMEN et al., 2005), wurden die landwirtschaftlichen Betriebsleiter gebeten, ihre Risikoeinstellung auf einer Skala von 0 (gar nicht risikobereit) bis 10 (sehr risikobereit) einzuschätzen. Im Mittel schätzen sich die Betriebsleiter als risikoneutral ein (5,5 auf der Skala). 
Der Stichprobenanteil biogaserzeugender Betriebe, die an einer Anlage beteiligt sind oder eine eigene Anlage betreiben, liegt mit 35 Betrieben bei 19,7\%. Insgesamt werden auf $97(54,5 \%)$ der befragten Betriebe Energiepflanzen angebaut. 73 landwirtschaftliche Betriebsleiter sind Substratlieferverträge eingegangen (41,0\%) und verfügen somit über direkte Erfahrungen. 105 Betriebsleiter haben keine derartigen Verträge abgeschlossen (59,0\%).

Tabelle 2. Durchschnittliche betriebsstrukturelle und sozioökonomische Charakteristika der Stichprobe und Deutschlands ${ }^{\text {a) }}$

\begin{tabular}{|c|c|c|}
\hline & Stichprobe $^{\text {b) }}$ & Deutschland \\
\hline \multicolumn{3}{|l|}{ Erwerbscharakter des Betriebes } \\
\hline Haupterwerb & $86,0 \%$ & $45,0 \%{ }^{c)}$ \\
\hline Nebenerwerb & $14,0 \%$ & $55,0 \%{ }^{c)}$ \\
\hline \multicolumn{3}{|l|}{ Betriebstyp } \\
\hline Ackerbau & $45,4 \%$ & $16,9 \%$ d) \\
\hline Veredlung & $21,8 \%$ & $5,8 \%{ }^{d)}$ \\
\hline Futterbau & $5,2 \%$ & $43,7 \%{ }^{d}$ \\
\hline Gemischt & $25,9 \%$ & $21,1 \%$ d) \\
\hline Sonstige & $1,7 \%$ & $12,5 \%$ d) \\
\hline Flächenausstattung (ha LN) & $283,3(496,7)$ & $48,5^{c)}$ \\
\hline Bodenpunkte & $53,4(18,3)$ & $42,5^{\mathrm{e})}$ \\
\hline Anteil studierter Landwirte & $47,4 \%$ & n.a. \\
\hline Anteil weiblicher Landwirte & $4,1 \%$ & n.a. \\
\hline Alter der Landwirte (Jahre) & $43,1(12,6)$ & n.a. \\
\hline Wertschätzung unternehmerischer Freiheit & $4,2(0,6)^{f)}$ & n.a. \\
\hline Risikoeinstellung & $5,5(2,0)^{g)}$ & n.a. \\
\hline Anteil biogaserzeugender Betriebe & $19,7 \%$ & n.a. \\
\hline Anteil Energiepflanzenanbauer & $54,5 \%$ & n.a. \\
\hline Anteil mit Substratlieferverträgen & $41,0 \%$ & n.a. \\
\hline
\end{tabular}

a) Die Standardabweichung ist in Klammern angegeben.

b) Nicht alle Fragen wurden von allen Teilnehmern $(\mathrm{N}=178)$ beantwortet. Die Anzahl abgegebener Antworten schwankt zwischen 169 und 178

c) Quelle: BMELV (2010).

d) Quelle: BMELV (2011).

e) Die Bodenpunkte wurden für Niedersachsen angegeben. Quelle: NLS (2001).

f) Gemessen auf einer 5er-Skala mit 1 (trifft überhaupt nicht zu) bis 5 (trifft voll und ganz zu).

g) Selbsteinschätzung nach SOEP auf einer Skala von 0 (gar nicht risikobereit) bis 10 (sehr risikobereit).

Quelle: eigene Berechnungen 


\section{2 Überblick und Beurteilung der abgeschlossenen Substratlieferverträge}

Nachfolgend wird näher auf Substratlieferverträge eingegangen, die von den befragten Betrieben abgeschlossen wurden. Tabelle 3 zeigt eine Übersicht der Verträge. Diese werden nach der jeweiligen Vertragslaufzeit und der Regelung der Vergütung unterteilt. Bei 15,0 \% der Verträge wurde eine Laufzeit von null Jahren angegeben. Eine kurze Laufzeit von 1 bis 2 Jahren hat nahezu ein Drittel der Teilnehmer $(28,8 \%)$ vereinbart. Über ein Drittel $(34,3 \%)$ verfügt über Verträge mit einer Laufzeit von 3 bis 6 Jahren. Die verbleibenden 21,9\% der Befragten haben Verträge mit einer langen Laufzeit von 7 bis 20 Jahren abgeschlossen. Die untersuchten 73 Verträge haben im Durchschnitt eine Laufzeit von 5 Jahren.

Bei der Regelung der Vergütung wurde zwischen Festpreis-Verträgen und Marktpreis-Verträgen unterschieden. Unter Festpreis-Verträgen sind neben Verträgen mit über die gesamte Laufzeit festgeschriebenen Preisen auch Verträge mit einer Preisanpassung - wie beispielsweise in Form eines jährlichen Zuschlages von $1,5 \%$ - zu verstehen, wenn diese garantiert wird und nicht von der zukünftigen Entwicklung einer Bezugsgröße abhängt. Rund die Hälfte der befragten Betriebsleiter mit Substratlieferverträgen $(49,3 \%)$ hat einen Festpreis-Vertrag abgeschlossen. Bei diesen liegt die durchschnittliche Vertragslaufzeit bei 4,5 Jahren. Die andere Hälfte der Betriebsleiter mit Substratlieferverträgen ist im Wesentlichen Verträge mit Marktpreisen (45,2\%) eingegangen, mit einer durchschnittlichen Vertragslaufzeit von 5,8 Jahren. Die verbleibenden vier der 73 Substratlieferverträge konnten keiner der beiden Kategorien zugeordnet werden, weil beispielsweise ein Tausch des Substrates gegen eine Kartoffelfläche vereinbart war. Ein Vergleich der Vergütungsregelungen zeigt, dass Marktpreis-Verträge gegenüber Festpreis-Verträgen durchschnittlich eine um 1,3 Jahre längere Vertragslaufzeit haben. 
Tabelle 3. Übersicht über die abgeschlossenen Substratlieferverträge

\begin{tabular}{|c|c|c|c|c|c|c|c|c|c|c|c|c|c|c|c|}
\hline & \multicolumn{13}{|c|}{ Vertragslaufzeit (Jahre) } & \multicolumn{2}{|c|}{ Stichprobe Durchschnitt } \\
\hline & 0 & 1 & 2 & 3 & 4 & 5 & 6 & 8 & 9 & 10 & 11 & 12 & 20 & & $\begin{array}{c}\text { (Standard- } \\
\text { abweichung) }\end{array}$ \\
\hline $\begin{array}{l}\text { Festpreis- } \\
\text { Vertrag }\end{array}$ & 6 & 11 & 2 & 0 & 0 & 9 & 1 & 0 & 0 & 1 & 1 & 3 & 2 & $36(49,3)$ & $4,5(5,3)$ \\
\hline $\begin{array}{l}\text { Marktpreis- } \\
\text { Vertrag }\end{array}$ & 3 & 5 & 2 & 1 & 2 & 11 & 0 & 1 & 1 & 4 & 0 & 0 & 3 & $33(45,2)$ & $5,8(5,5)$ \\
\hline Sonstige $^{\text {a) }}$ & 2 & 1 & 0 & 0 & 0 & 1 & 0 & 0 & 0 & 0 & 0 & 0 & 0 & $4(5,5)$ & $1,5(2,4)$ \\
\hline $\begin{array}{l}\text { Stichprobe } \\
(\%)\end{array}$ & $\begin{array}{c}11 \\
(15,0)\end{array}$ & $\begin{array}{c}17 \\
(23,3)\end{array}$ & $\begin{array}{c}4 \\
(5,5)(\end{array}$ & $\begin{array}{c}1 \\
(1,4)\end{array}$ & $\begin{array}{c}2 \\
(2,7)\end{array}$ & $\begin{array}{c}21 \\
28,8)\end{array}$ & $\begin{array}{c}1 \\
(1,4)\end{array}$ & $\begin{array}{c}1 \\
(1,4)(\end{array}$ & $\begin{array}{c}1 \\
(1,4)\end{array}$ & $\begin{array}{c}5 \\
(6,8)\end{array}$ & $\begin{array}{c}1 \\
(1,4)\end{array}$ & $\begin{array}{c}3 \\
(4,1)\end{array}$ & $\begin{array}{c}5 \\
(6,8)\end{array}$ & $\begin{array}{l}73 \\
(100,0)\end{array}$ & $5,0(5,3)$ \\
\hline
\end{tabular}

a) Ein Teilnehmer hat keine Angaben bezüglich der Preisausgestaltung gemacht.

Quelle: eigene Berechnungen

Des Weiteren wurden die landwirtschaftlichen Betriebsleiter um eine Beurteilung der von innen abgeschlossenen Substratlieferverträge gebeten (Tabelle 4). Rund 8\% empfinden die Vertragslaufzeit im Nachhinein als zu kurz. Über $80 \%$ der Befragten sind mit der gewählten Vertragslaufzeit zufrieden. $11 \%$ beurteilen die eingegangene Laufzeit als zu lang. Dabei wird die Laufzeit bei Festpreis-Verträgen eher als zu lang und bei Marktpreis-Verträgen eher als zu kurz eingeschätzt.

Hinsichtlich der Beurteilung der Vergütung empfinden ca. 20\% der Befragten diese als viel zu niedrig, rund $80 \%$ als angemessen und 2,7\% als sehr auskömmlich. Inwiefern bei dieser optimistischen Aussage strategische Erwägungen, im Sinne einer „zurückhaltenden Einschätzung“, um die eigene Verhandlungsposition bei zukünftigen Verträgen nicht zu schwächen, eine Rolle gespielt haben, bleibt zu hinterfragen. Bei einer Unterteilung in Gruppen zeigt sich, dass die Vergütung von der Gruppe mit Festpreis-Verträgen zu 72,2\% und von der Gruppe mit MarktpreisVerträgen zu $87,9 \%$ als angemessen eingeschätzt wird. Ein Viertel der ersten Gruppe, aber nur 9,1\% der zweiten Gruppe geben die Vergütung als viel zu niedrig an. Insgesamt zeigt sich die zweite Gruppe mit der gewählten Vergütungsregelung zufriedener. 
Tabelle 4. Beurteilung von bestehenden Substratlieferverträgen $(n=73)$

\begin{tabular}{|c|c|c|c|c|c|c|}
\hline & \multicolumn{3}{|c|}{ Vertragslaufzeit } & \multicolumn{3}{|c|}{ Regelung der Vergütung } \\
\hline & zu kurz & passend & zu lang & $\begin{array}{l}\text { viel zu } \\
\text { niedrig }\end{array}$ & $\begin{array}{c}\text { an- } \\
\text { gemessen }\end{array}$ & $\begin{array}{l}\text { sehr aus- } \\
\text { kömmlich }\end{array}$ \\
\hline $\begin{array}{l}\text { Festpreis-Vertrag (\%) } \\
(n=36)\end{array}$ & 5,6 & 77,8 & 16,7 & 25,0 & 72,2 & 2,8 \\
\hline $\begin{array}{l}\text { Marktpreis-Vertrag (\%) } \\
(n=33)\end{array}$ & 9,1 & 84,8 & 6,1 & 9,1 & 87,9 & 3,0 \\
\hline Sonstige $^{\text {a) }}(\%)(n=4)$ & 25,0 & 75,0 & 0,0 & 50,0 & 50,0 & 0,0 \\
\hline Stichprobe (\%) & $\begin{array}{c}6 \\
(8,2)\end{array}$ & $\begin{array}{c}59 \\
(80,8)\end{array}$ & $\begin{array}{c}8 \\
(11,0)\end{array}$ & $\begin{array}{c}14 \\
(19,2)\end{array}$ & $\begin{array}{c}57 \\
(78,1)\end{array}$ & $\begin{array}{c}2 \\
(2,7)\end{array}$ \\
\hline
\end{tabular}

a) Ein Teilnehmer hat keine Angaben bezüglich der Preisausgestaltung gemacht.

Quelle: eigene Berechnungen

\section{Ergebnisse}

\subsection{Gewünschte Vertragsmerkmale und deren Stellenwert}

Für den Großteil der befragten Betriebsleiter $(87,3 \%)$ ist es bedeutsam, dass der Vertragspartner Verständnis für die speziellen Bedingungen in der Landwirtschaft hat. Zudem ist rund $77,1 \%$ der Betriebsleiter wichtig, dass die wirtschaftliche Situation des Vertragspartners transparent ist. Für fast die Hälfte der Landwirte $(48,4 \%)$ sollte der Vertragspartner aus der Region stammen. 18,8\% der Befragten lehnen dieses hingegen ab.

Die Betriebsleiter wurden zudem in einer offenen Frage um die Angabe einer bevorzugten Laufzeit für Festpreis-Verträge und gewünschte Bezugsgrößen für Marktpreis-Verträge gebeten (Tabelle 5). Von den Betriebsleitern geben 1,7\% eine gewünschte Vertragslaufzeit von null an. Dieses könnte bedeuten, dass sie sich zeitlich nicht festlegen wollen oder alternativ, keinen Vertrag abzuschließen wünschen. Die häufigsten Angaben liegen mit $14,0 \%$ bei einem Jahr, 34,8\% bei 3 Jahren und $27,5 \%$ bei 5 Jahren. Der Mittelwert der Gesamtstichprobe beträgt 3,6 Jahre (Standardabweichung: 2,2). Die Betriebsleiter, die keine Substratlieferverträge abgeschlossen haben, geben durchschnittlich eine gewünschte Laufzeit von 3,1 Jahren an (Standardabweichung: 1,6). Demgegenüber wünschen die Betriebsleiter mit Verträgen im Mittel eine Laufzeit von 4,3 Jahren (Standardabweichung: 2,7). Diese ist somit geringer als die durchschnittliche Laufzeit (5,0 Jahre) der abgeschlossenen Verträge (Tabelle 4). Die Teilnehmer mit Festpreis-Verträgen geben eine gewünschte durchschnittliche Laufzeit von 4,6 Jahren (Standardabweichung: 3,4) und Teilnehmer mit Marktpreis-Verträgen von 4,0 Jahren (Standardabweichung: 1,9$)$ an. 
Da sich eine Vergütung zu Marktpreisen an verschiedenen Preisen orientieren kann, wurde zudem erfragt, an welchem (Referenz-)Preis diese gekoppelt werden sollte. Dazu wurden vier Bezugsgrößen zur Auswahl gestellt. Diese konnten einzeln ausgewählt oder gewichtet werden. Mit Abstand den größten Zuspruch fand der Getreidepreis (Weizenpreis) als Referenzgröße. Dieser wurde von rund der Hälfte der Befragten (52,7\%) ausgewählt und bestätigt damit die Einschätzung aus den Pretests und Expertengesprächen hinsichtlich der Berücksichtigung im CE. Mit jeweils rund $17 \%$ wurden eine Kopplung an die allgemeinen Produktionskosten in der Landwirtschaft und die Energiepreisentwicklung angegeben. Die Kosten der Arbeitserledigung (wie z.B. Lohnkosten, Treibstoffkosten, Lohnunternehmerpreise) erhielten einen Anteil von 13,9\%.

Tabelle 5. Gewünschte Laufzeit bei Festverträgen und gewünschte Bezugsgröße für Marktpreis-Verträge

\begin{tabular}{lr}
\hline & Prozent \\
\hline Laufzeit Festpreis-Vertrag ( $\mathrm{N}=178)$ & $1,7 \%$ \\
keine (0 Jahre) & $23,0 \%$ \\
kurz (1-2 Jahre) & $70,8 \%$ \\
mittel (3-6 Jahre) & $4,5 \%$ \\
lang (7-20 Jahre) & $52,7 \%$ \\
\hline Bezugsgröße Marktpreis-Vertrag & $16,6 \%$ \\
Getreidepreise (Weizenpreis) $(n=147)$ & $16,8 \%$ \\
Produktionskosten in der Landwirtschaft allgemein ( $=104)$ & $13,9 \%$ \\
Energiepreisentwicklung ( $\mathrm{n}=108)$ & \\
Kosten der Arbeitserledigung $(\mathrm{n}=99)$ &
\end{tabular}

Quelle: eigene Berechnungen

Die Teilnehmer wurden außerdem gebeten, ihre persönliche Einschätzung bezüglich des Stellenwertes von verschiedenen Vertragsmerkmalen bei der Vertragsgestaltung zu äußern. Dazu mussten die vier Merkmale - Verkaufspreis, Vertragspartner, Vertragslaufzeit und Liefermenge - in eine Rangfolge nach ihrer Wichtigkeit gebracht werden. Tabelle 6 zeigt, dass dem Verkaufspreis die höchste Bedeutung (Gesamtrang 1) beigemessen wird, gefolgt vom jeweiligen Vertragspartner (Gesamtrang 2). Der 3. Gesamtrang wird der Vertragslaufzeit zugeordnet. Die Liefermenge liegt auf dem 4. Gesamtrang und bestätigt damit die Aussage aus den Pretests und Expertengesprächen hinsichtlich der untergeordneten Bedeutung dieses Merkmals. 
Tabelle 6. Rangfolge von Vertragsmerkmalen ${ }^{\text {a) }}$

\begin{tabular}{lcccc}
\hline & $\begin{array}{c}\text { Verkaufspreis } \\
(\mathrm{n}=174)\end{array}$ & $\begin{array}{c}\text { Vertragspartner } \\
(\mathrm{N}=178)\end{array}$ & $\begin{array}{c}\text { Vertragslaufzeit } \\
(\mathrm{n}=174)\end{array}$ & $\begin{array}{c}\text { Liefermenge } \\
(\mathrm{n}=173)\end{array}$ \\
\hline Rang 1 & $60,9 \%$ & $27,5 \%$ & $9,8 \%$ & $3,5 \%$ \\
Rang 2 & $30,5 \%$ & $19,7 \%$ & $29,3 \%$ & $20,2 \%$ \\
Rang 3 & $7,5 \%$ & $19,1 \%$ & $40,8 \%$ & $32,4 \%$ \\
Rang 4 & $1,1 \%$ & $33,7 \%$ & $20,1 \%$ & $43,9 \%$ \\
\hline Mittelwert & 1,5 & 2,6 & 2,7 & 3,2 \\
\hline Gesamtrang & 1 & 2 & 3 & 4 \\
\hline
\end{tabular}

a) Von Rang 1 (= am wichtigsten) bis Rang 4 (= am unwichtigsten).

Quelle: eigene Berechnungen

\subsection{Ergebnisse des CE zur Überprüfung der Hypothesen}

Die Auswertung des CE basiert auf der Untersuchung der einzelnen Auswahlentscheidungen. Die Teilnehmer konnten jeweils zwischen den drei Alternativen „Festpreis-Vertrag“, „Marktpreis-Vertrag“ und Opt-out-Alternative auswählen. Jeder Betriebsleiter hat während der Befragung 9 Auswahlentscheidungen zwischen diesen 3 Alternativen getroffen. Somit liegen bei den 178 Teilnehmern insgesamt $(9 * 3 * 178=) 4.806$ Beobachtungen (observations) vor.

Mittels der Software Stata 11 werden auf Basis der Daten des CE konditionale Logit-Modelle geschätzt. Auf diese Weise soll der Einfluss der verschiedenen zu untersuchenden Vertragsmerkmale auf die Wahrscheinlichkeit einer Vertragsauswahl bestimmt werden. Die nachfolgend dargestellten Ergebnisse sind auch dann robust, wenn Modelle, die im Vergleich zu konditionalen Logit-Modellen weniger strenge Annahmen voraussetzen, verwendet werden (z.B. mixed Logit-Modelle, die u.a. den Panelcharakter der Daten berücksichtigen; hier nicht dargestellt).

Tabelle 7 berichtet Ergebnisse von konditionalen Logit-Modellen unter Ausschluss der Opt-out-Alternative, d.h. es gehen nur Auswahlentscheidungen in die Analyse ein, bei denen ein Festpreis- oder Marktpreis-Vertrag gewählt wurde (2.304 Beobachtungen). Die Ergebnisse von Modellschätzungen mit und ohne Opt-outAlternative unterscheiden sich jedoch kaum. Zudem sollte diese Alternative nur gewählt werden, wenn sich die Teilnehmer nicht zwischen den angebotenen Verträgen entscheiden können. Sie hat demnach eher methodischen als inhaltlichen Charakter. Auch dies unterstützt den Ausschluss der Opt-out-Alternative von den Analysen.

In Modell A wird zunächst davon ausgegangen, dass die Merkmale dieselben Effekte auf die Auswahl eines Festpreis- oder Marktpreis-Vertrages haben (generische Effekte). Gegeben diese Annahme wird deutlich, dass die Befragten Bioener- 
giedörfer und Landwirte gegenüber außerlandwirtschaftlichen Investoren als Vertragspartner bevorzugen (signifikant positive Effekte). Dies stützt Hypothese 1, nach der Unterschiede in der Wahrscheinlichkeit einer Vertragsauswahl in Abhängigkeit vom Vertragspartner erwartet werden. In Bezug auf die anderen untersuchten Vertragsmerkmale lassen sich folgende Wirkungsrichtungen feststellen: Mit steigender Vertragslaufzeit sinkt die Attraktivität eines Vertrages (signifikant negativer Effekt) und ein zunehmender Verkaufspreis erhöht die Attraktivität (signifikant positiver Effekt).

Unter Verwendung der Modelle B, C und D wird untersucht, inwieweit Unterschiede zwischen Festpreis- und Marktpreis-Verträgen bestehen. Modell B zeigt, dass bei Festpreis-Verträgen der negative Effekt der Vertragslaufzeit geringer ist als bei Marktpreis-Verträgen $(-0,02=-0,14+0,12$ versus $-0,14)$. Allerdings ist der positive Effekt des Verkaufspreises bei Festpreis-Verträgen höher als bei MarktpreisVerträgen $(0,17=0,04+0,13$ versus 0,04$)$. Die Modelle $C$ und $D$ verdeutlichen, dass bei Marktpreis-Verträgen ein Bioenergiedorf als Vertragspartner attraktiver ist als bei Festpreis-Verträgen (negativer Interaktionseffekt für Festpreis * Bioenergiedorf), während bei Festpreis-Verträgen Landwirte als Vertragspartner eher bevorzugt werden als bei Marktpreis-Verträgen (positiver Interaktionseffekt für Festpreis * Landwirt).

Teilt man die Koeffizienten der nicht-monetären Merkmale durch das monetäre Merkmal ergeben sich beispielhaft folgende implizite Preise (95\% Konfidenzintervalle in Klammern, nach dem Krinsky-Robb-Verfahren, KRINSKY und ROBB, 1986; unter Verwendung von 1.000 Replikationen): Für ein Jahr zusätzliche Vertragslaufzeit müssten die Landwirte im Durchschnitt bei einem Marktpreis-Vertrag eine zusätzliche Vertragsprämie in Höhe von $3,36(1,82$ bis 6,88$) €$ pro Tonne Silomais als Kompensation erhalten. Zudem wären Landwirte bei Marktpreis-Verträgen im Mittel bereit, auf $12,16(1,73$ bis 26,82$) €$ pro Tonne zu verzichten, wenn der Vertragspartner ein Bioenergiedorf ist. Dieses hohe Preisniveau zeigt Bedarf für weiterführende Untersuchungen auf. Möglicherweise hat der Begriff „Bioenergiedorf“ falsche Assoziationen bei den Befragungsteilnehmern hervorgerufen. Demgegenüber könnte der hohe Betrag aber auch außerökonomische Intentionen der Betriebsleiter zeigen (z.B. ein erwarteter Imagegewinn). Die impliziten Preise verdeutlichen nochmal die Gültigkeit von Hypothese 1: Der Vertragspartner ist bei der Auswahl von Verträgen von Bedeutung. 
Tabelle 7. Ergebnisse der konditionalen Logitmodelle ${ }^{\text {a) }}$

\begin{tabular}{|c|c|c|c|c|}
\hline & A & B & C & D \\
\hline Festpreis (Konstante) & $\begin{array}{c}0,14^{+} \\
(1,92)\end{array}$ & $\begin{array}{c}0,04 \\
(0,50)\end{array}$ & $\begin{array}{l}0,31^{+} \\
(1,91)\end{array}$ & $\begin{array}{c}-0,20 \\
(-1,44)\end{array}$ \\
\hline Bioenergiedorf & $\begin{array}{l}0,26^{*} \\
(2,37)\end{array}$ & $\begin{array}{c}0,24^{*} \\
(2,15)\end{array}$ & $\begin{array}{l}0,50^{*} \\
(2,45)\end{array}$ & \\
\hline Festpreis * Bioenergiedorf & & & $\begin{array}{c}-0,79^{*} \\
(-2,15)\end{array}$ & \\
\hline Landwirt & $\begin{array}{l}0,24^{*} \\
(2,32)\end{array}$ & $\begin{array}{l}0,26^{*} \\
(2,15)\end{array}$ & & $\begin{array}{c}-0,21 \\
(-1,13)\end{array}$ \\
\hline Festpreis * Landwirt & & & & $\begin{array}{l}0,71^{*} \\
(2,15)\end{array}$ \\
\hline Laufzeit & $\begin{array}{l}-0,08^{*} \\
(-5,90)\end{array}$ & $\begin{array}{l}-0,14^{\star} \\
(-4,62)\end{array}$ & $\begin{array}{l}-0,14^{*} \\
(-4,62)\end{array}$ & $\begin{array}{l}-0,14^{*} \\
(-4,62)\end{array}$ \\
\hline Festpreis * Laufzeit & & $\begin{array}{c}0,12^{*} \\
(2,27)\end{array}$ & $\begin{array}{l}0,12^{*} \\
(2,27)\end{array}$ & $\begin{array}{c}0,12^{*} \\
(2,27)\end{array}$ \\
\hline Preis & $\begin{array}{c}0,10^{*} \\
(16,50)\end{array}$ & $\begin{array}{c}0,04^{*} \\
(3,99)\end{array}$ & $\begin{array}{l}0,04^{*} \\
(3,99)\end{array}$ & $\begin{array}{l}0,04^{*} \\
(3,99)\end{array}$ \\
\hline Festpreis * Preis & & $\begin{array}{c}0,13^{*} \\
(6,67)\end{array}$ & $\begin{array}{l}0,13^{*} \\
(6,67)\end{array}$ & $\begin{array}{l}0,13^{*} \\
(6,67)\end{array}$ \\
\hline Log-likelihood & $-574,49$ & $-546,15$ & $-546,15$ & $-546,15$ \\
\hline Pseudo-R ${ }^{2}$ & 0,28 & 0,32 & 0,32 & 0,32 \\
\hline Beobachtungen & 2.304 & 2.304 & 2.304 & 2.304 \\
\hline
\end{tabular}

a) ${ }^{+} p<0,10$; ${ }^{*} p<0,05$; $z$-Werte in Klammern. In den Modellen A und B ist „Investoren“ die Referenzkategorie für die Vertragspartner "Bioenergiedorf“ und „Landwirte“; in den Modellen C und D sind jeweils „Investoren“ und „Landwirte“ bzw. „Investoren“ und „Bioenergiedorf“ die Referenzkategorie.

Quelle: eigene Berechnungen

In Tabelle 8 sind Unterschiede zwischen den Befragten dargestellt (Heterogenität). Diese lassen Rückschlüsse auf die Gültigkeit der Hypothesen 2, 3 und 4 zu. Den Hypothesen folgend werden drei Befragtenmerkmale betrachtet: (1) Wertschätzung unternehmerischer Freiheit, (2) Selbsteinschätzung der Risikoeinstellung und (3) Erfahrung mit Substratlieferverträgen. Bezogen auf die unternehmerische Freiheit wird deutlich, dass Landwirte mit einer sehr hohen Wertschätzung für unternehmerische Freiheit die Vertragslaufzeit bei Marktpreis-Verträgen negativer bewerten als Landwirte mit einer geringeren Wertschätzung für unternehmerische Freiheit (Koeffizienten von -0,21 versus -0,12). Die entsprechenden impliziten Preise zeigen, dass bei Marktpreis-Verträgen für ein Jahr zusätzliche Vertragslaufzeit die Landwirte, die der unternehmerischen Freiheit eine sehr hohe Bedeutung beimessen, im Durchschnitt eine Vertragsprämie in Höhe von 3,98 (95\% Konfidenzintervall: 1,80 bis 11,22$) €$ und die Landwirte, die der unternehmerischen Freiheit eine eher geringe Bedeutung beimessen, eine Vertragsprämie in Höhe von 3,52 (95\% 
Konfidenzintervall: 1,05 bis 14,50$) €$ pro Tonne Silomais zusätzlich erhalten müssten. Dies spricht für Hypothese 2; jedoch zeigen die sich überlappenden Konfidenzintervalle nicht-signifikante Unterschiede in den impliziten Preisen zwischen den beiden Gruppen an.

Eine Tendenz, dass risikoaverse Landwirte Festpreis-Verträge gegenüber Marktpreis-Verträgen bevorzugen, kann nicht bestätigt werden: Die Konstante für die Alternative Festpreis ist sowohl im Modell für risikoaverse Landwirte als auch nicht risikoaverse Landwirte statistisch nicht signifikant. Es gibt demnach (über den Erklärungsbeitrag der Vertragsmerkmale hinaus) keine generelle Tendenz, dass risikoaverse Landwirte die Festpreis-Alternative gegenüber der MarktpreisAlternative bevorzugen. Allerdings zeigt sich, dass bei risikoaversen Landwirten der Effekt für die Prämie (Preisattribut) deutlich geringer ist als in der Gruppe der risikoneutralen und -freudigen Landwirte. Dies steht in Einklang mit Hypothese 3 und bestätigt sich zudem in einem Gesamtmodell für alle Befragten und mit Interaktionseffekten zwischen Vertrags- und Befragtenmerkmalen, da der Interaktionseffekt zwischen der Risikovariablen und dem Preisattribut statistisch signifikant ist (hier nicht dargestellt).

Mit Blick auf Hypothese 4 zeigen sich nur geringfügige Unterschiede zwischen Landwirten, die bereits einen Substratliefervertrag abgeschlossen haben, und jenen, die noch keinen Vertrag abgeschlossen haben. Landwirte mit Vertrag bevorzugen eher ein Bioenergiedorf als Vertragspartner gegenüber außerlandwirtschaftlichen Investoren (signifikanter Effekt auf dem 10\%-Niveau) und die Laufzeit wird bei Festpreis-Verträgen signifikant weniger stark negativ bewertet als bei MarktpreisVerträgen. Beide Effekte finden sich in der Gruppe der Landwirte ohne Vertragserfahrung nicht. 
Tabelle 8. Ergebnisse der konditionalen Logitmodelle zu Heterogenität ${ }^{\text {a) }}$

\begin{tabular}{lcccccc}
\hline & \multicolumn{2}{c}{$\begin{array}{c}\text { Bedeutung unterneh- } \\
\text { merischer Freiheit }\end{array}$} & $\begin{array}{c}\text { Selbsteinstufung der } \\
\text { Risikoneigung }\end{array}$ & \multicolumn{2}{c}{$\begin{array}{c}\text { Substratliefervertrag } \\
\text { tatsächlich vorhanden }\end{array}$} \\
\cline { 2 - 7 } & gering & $\begin{array}{c}\text { sehr } \\
\text { hoch }\end{array}$ & $\begin{array}{c}\text { risiko- } \\
\text { avers }\end{array}$ & $\begin{array}{c}\text { nicht } \\
\text { risikoavers }\end{array}$ & nein & ja \\
\hline Festpreis (Konstan- & $-0,08$ & $0,29^{*}$ & $-0,19$ & 0,13 & 0,06 & 0,03 \\
te) & $(-0,69)$ & $(2,00)$ & $(-1,22)$ & $(1,33)$ & $(0,55)$ & $(0,24)$ \\
Bioenergiedorf & 0,19 & 0,16 & 0,12 & $0,30^{*}$ & 0,21 & $0,29^{+}$ \\
& $(1,27)$ & $(0,86)$ & $(0,55)$ & $(2,30)$ & $(1,38)$ & $(1,76)$ \\
Landwirt & 0,15 & $0,37^{+}$ & 0,16 & $0,33^{*}$ & 0,28 & 0,25 \\
& $(0,92)$ & $(1,65)$ & $(0,70)$ & $(2,21)$ & $(1,63)$ & $(1,37)$ \\
Laufzeit & $-0,12^{*}$ & $-0,21^{*}$ & $-0,13^{*}$ & $-0,15^{*}$ & $-0,15^{*}$ & $-0,12^{*}$ \\
Festpreis * Laufzeit & $(-3,03)$ & $(-3,84)$ & $(-2,30)$ & $(-4,03)$ & $(-3,67)$ & $(-2,66)$ \\
& 0,05 & $0,25^{*}$ & 0,03 & $0,15^{*}$ & 0,06 & $0,18^{*}$ \\
Preis & $(0,82)$ & $(2,60)$ & $(0,37)$ & $(2,43)$ & $(0,92)$ & $(2,27)$ \\
& $0,03^{*}$ & $0,05^{*}$ & $0,06^{*}$ & $0,04^{*}$ & $0,05^{*}$ & $0,03^{*}$ \\
Festpreis * Preis & $(2,43)$ & $(2,98)$ & $(3,16)$ & $(2,93)$ & $(3,34)$ & $(2,28)$ \\
& $0,17^{*}$ & $0,09^{*}$ & $0,06^{+}$ & $0,15^{*}$ & $0,11^{*}$ & $0,15^{*}$ \\
\hline Log-likelihood & $(6,38)$ & $(2,81)$ & $(1,67)$ & $(6,67)$ & $(4,36)$ & $(5,13)$ \\
\hline Pseudo-R ${ }^{2}$ & $-339,77$ & $-174,27$ & $-142,94$ & $-396,89$ & -295.62 & -244.29 \\
Beobachtungen & 0,36 & 0,29 & 0,30 & 0,33 & 0,32 & 0,32 \\
\hline & 1.540 & 708 & 590 & 1.714 & 1.270 & 1.034 \\
\hline
\end{tabular}

a) ${ }^{+} p<0,10 ;{ }^{*} p<0,05 ; z$-Werte in Klammern. In allen Modellen sind "Investoren“ die Referenzkategorie für die Vertragspartner „Bioenergiedorf“ und „Landwirte“. Bei Freiheit sind Befragte in der Gruppe „sehr hoch“, wenn sie folgender Aussage voll und ganz zustimmen: „Als Landwirt ist mir meine unternehmerische Freiheit wichtig.“ Risikoaverse Landwirte haben auf der Selbsteinschätzung der Risikoeinstellung geringere Werte als 5 und bei Substratlieferverträgen wurde gefragt, ob der Landwirt bereits einen Vertrag abgeschlossen hat.

Quelle: eigene Berechnungen

\section{Schlussfolgerungen und Ausblick}

Für die Erzeugung erneuerbarer Energien in Biogasanlagen ist die Versorgung mit Substraten notwendig. Die Kosten für das Substrat sind von erheblicher Bedeutung, da diese bei einer Biogasanlage rund die Hälfte der jährlichen Kosten ausmachen. Bei größeren Anlagen, bei denen vielfach eine Substratzulieferung durch Dritte erforderlich ist, stellt sich die Frage, wie Lieferverträge ausgestaltet sein sollten, damit diese von einer ausreichenden Zahl an Landwirten angenommen werden. $\mathrm{Zu}$ einzelnen Vertragsparametern gibt es intuitive Vorstellungen. Beispielsweise sollte grundsätzlich ein höherer Verkaufspreis c.p. bevorzugt werden. Ziel dieses Beitrags ist es, wesentliche Faktoren für den Abschluss von Substratlieferverträgen für Mais aufzuzeigen und quantitative Aussagen zu der Bedeutung von ausgewählten Vertragsbestandteilen abzuleiten. Dabei findet die Interaktion von Vertragsmerkmalen Berücksichtigung. 
Wir haben 178 landwirtschaftliche Betriebsleiter befragt, von denen etwa die Hälfte bereits Substratlieferverträge abgeschlossen hat. Die direkte Abfrage in Form einer Rangfolge zeigt den unterschiedlichen Stellenwert von verschiedenen Vertragsmerkmalen. Dem Verkaufspreis kommt die größte Bedeutung zu. Der Vertragspartner und die -laufzeit haben eine mittlere Relevanz. Die Liefermenge hingegen ist von eher untergeordneter Bedeutung.

Im Rahmen des CE wurden die Merkmale „Vertragspartner“ (andere Landwirte, ein Bioenergiedorf und außerlandwirtschaftliche Investoren), „Vertragslaufzeit“ (1, 5 und 9 Jahre) und „Verkaufspreis“ (diverse Fest- und Marktpreise) untersucht, indem konditionale Logit-Modelle geschätzt wurden. Bei der Untersuchung der Vertragsmerkmale zeigt sich, dass die Art des Vertragspartners bei der Beurteilung eines Vertrages für die befragten Betriebsleiter relevant ist: Die Teilnehmer ziehen einen Vertrag mit einem Bioenergiedorf oder anderen Landwirten einem Vertrag mit außerlandwirtschaftlichen Investoren vor. Die Attraktivität eines Vertrages sinkt mit der Laufzeit und steigt mit dem Verkaufspreis. Die Untersuchung der Befragtenmerkmale zeigt, dass den Teilnehmern im Mittel ihre unternehmerische Freiheit von großer Bedeutung ist. Landwirte, die ihre unternehmerische Freiheit sehr wertschätzen, verlangen im Durchschnitt eine höhere Prämie für ein zusätzliches Jahr vertraglicher Bindung, als Landwirte, für die dieser Aspekt nicht im Vordergrund steht. Es konnte nicht bestätigt werden, dass Festpreis-Verträge von risikoaversen Landwirten gegenüber Marktpreis-Verträgen bevorzugt werden. Eine mögliche Ursache hierfür könnte in der Annahme konstanter Preiserwartungen begründet sein. Hinsichtlich eines Effekts aus „Erfahrungen“ bleibt festzustellen, dass sich das Auswahlverhalten der Landwirte, die keine Substratlieferverträge abgeschlossen haben, und den Landwirten mit Erfahrungen durch abgeschlossene Substratlieferverträge, nicht stark unterscheidet. Jedoch beurteilen Landwirte ohne Substratlieferverträge im Gegensatz zu Befragten mit Substratlieferverträgen eine zunehmende Laufzeit von Verträgen zu Festpreisen weniger negativ als bei Verträgen zu Marktpreisen.

Im Hinblick auf die Interpretation der Ergebnisse ist zu bedenken, dass die Entscheidungsträger in der realen Welt, wo es um „echtes Geld“ geht, einen höheren Anreiz haben, möglichst optimale Entscheidungen zu treffen. In zukünftigen Untersuchungen könnte man analysieren, inwiefern im Experiment gesetzte finanzielle Anreize für "scharfes Nachdenken“ die Ergebnisse beeinflussen. So könnte man im Experiment z.B. eine bestimmte zu vermarktende Substratliefermenge vorgeben und reale Auszahlungen an den Vermarktungserfolg koppeln, der sich 
in einem ausgewählten Choice-Set bei der vom jeweiligen Teilnehmer gewählten Alternative ergibt. Außerdem wird die abschließende Beurteilung eines Vertrages über die hier untersuchten Hauptvertragsmerkmale hinausgehen. In der Praxis ist es notwendig, alle Aspekte eines Vertrages simultan zu betrachten (BOGETOFT und OLESEN, 2002). Zudem wäre es in zukünftigen Untersuchungen interessant, noch stärker nach betriebsstrukturellen und regionalen Rahmenbedingungen zu differenzieren. Überdies ist wichtig, welches Substrat angebaut werden soll. Durch die zunehmende Verbreitung ist Mais gegenwärtig in die Kritik geraten. Risiken des Maisanbaus liegen z.B. in einer engen Fruchtfolge (bis hin zu Monokulturen) und zunehmendem Düngemittel- und Herbizideinsatz (vgl. BFN, 2010). Alternative Substrate, wie beispielsweise die Durchwachsene Silphie, sind noch nicht stark verbreitet und erfordern im Hinblick auf Substratlieferverträge weitergehende Untersuchungen. Dabei sollte auch die unterschiedliche Transportwürdigkeit Berücksichtigung finden. Beispielsweise untersuchen SCHULZE STEINMANN und HOLM-MÜLlER (2010) dazu verschiedene Substrate mit Hilfe der Thünenschen Ringe. Zudem besteht weiterer Forschungsbedarf hinsichtlich möglicher Bezugsgrößen für Preisanpassungsklauseln.

\section{Literatur}

AdAmowicz, W., J.J. LouvieRE und M. Williams (1994): Combining Revealed and Stated Preference Methods for Valuing Environmental Amenities. In: Journal of Environmental Economics and Management 26 (3): 271-292.

Andersen, S., G.W. HarRison, M. LAU und E.E. RutStRÖM (2008): Eliciting Risk and Time Preferences. In: Econometrica 76 (3): 583-618.

ARNDT, U., S. VON ROON und U. WAGNER (2006): Virtuelle Kraftwerke: Theorie oder Realität? In: BWK Energie-Fachmagazin 58 (6): 52-57.

AusPuRG, K. und U. LIEBE (2011): Choice-Experimente und die Messung von Handlungsentscheidungen in der Soziologie. In: Kölner Zeitschrift für Soziologie und Sozialpsychologie 63 (2): 301-314.

BAHRS, E., S. KROLL und M. SUTTER (2008): Trading Agricultural Payment Entitlements: An Experimental Investigation of Bilateral Negotiations. In: American Journal of Agricultural Economics 90 (5): 1201-1207.

BARD, S.K. und P.J. BERRY (2000): Developing a Scale for Assessing Risk Attitudes of Agricultural Decision Maker. In: International Food and Agribusiness Management Review 3 (1): 9-25. 
BENZ, M. (2006): Entrepreneurship as a Non-profit-seeking Activity. In: International Entrepreneurship and Management Journal 5 (1): 23-44.

BFN (Bundesamt für Naturschutz) (2010): Bioenergie und Naturschutz. Synergien fördern, Risiken vermeiden. Bonn.

BMELV (Bundesministerium für Ernährung, Landwirtschaft und Verbraucherschutz) (2010): Ausgewählte Daten und Fakten der Agrarwirtschaft 2010. Bonn.

BMELV (Bundesministerium für Ernährung, Landwirtschaft und Verbraucherschutz) (2011): Agrarpolitischer Bericht der Bundesregierung 2011. Bonn.

BMU (Bundesministerium für Umwelt, Naturschutz und Reaktorsicherheit) und BMELV (Bundesministerium für Ernährung, Landwirtschaft und Verbraucherschutz) (2009): Nationaler Biomasseaktionsplan für Deutschland. Beitrag der Biomasse für eine nachhaltige Energieversorgung. Berlin und Bonn.

Bogetoft, P. und H.B. Olesen (2002): Ten Rules of Thumb in Contract Design: Lessons from Danish Agriculture. In: European Review of Agricultural Economics 29 (2): 185-204.

BougherarA, D. und G. Ducos (2006): Farmers' Preferences over Conservation Contract Flexibility and Duration: An Estimation of the Effect of Transaction Costs using Choice Experiment. In: http://www.prodinra.inra.fr/prodinra/pinra/data/2007/ 06/PROD2007442e9b20_20070605011110878.pdf. Abruf: 06.12.2011.

BuRGESS, L. und D.J. STREET (2005): Optimal Designs for Choice Experiments with Asymmetric Attributes. In: Journal of Statistical Planning and Inference 134 (1): 288-301.

CAMERON, L.A. (1999): The Importance of Learning in the Adoption of High-Yielding Variety Seeds. In: American Journal of Agricultural Economics 81 (1): 83-94.

CheUnG, Y.-W. und D. Friedman (1998): A Comparison of Learning and Replicator Dynamics using Experimental Data. In: Journal of Economic Behavior and Organization 35 (3): 263-280.

DMK (Deutsches Maiskommitee e.V.) (2011): Bedeutung des Maisanbaus in Deutschland. In: http://www.maiskomitee.de/web/intranetHomepages.aspx?hp= 30a01c5a-cb8c-9314-9398-742c9d12a03e. Abruf: 21.12.2011.

Dohmen, T., A. Falk, D. Huffman, U. Sunde, J. Schupp, und G.G. WAGner (2005): Individual Risk Attitudes: New Evidence from a Large, Representative, Experi- 
mentally-Validated Survey. Diskussionsbeitrag Nr. 511. Deutsches Institut für Wirtschaftsforschung.

ENNEKING, U. (2003): Die Analyse von Lebensmittelpräferenzen mit Hilfe von Discrete-Choice-Modellen am Beispiel ökologisch produzierter Wurstwaren. In: Agrarwirtschaft 52 (5): 254-267.

FNR (Fachagentur Nachwachsende Rohstoffe e.V.) (2007): Studie Einspeisung von Biogas in das Erdgasnetz. 3. Auflage. Gülzow.

FNR (Fachagentur Nachwachsende Rohstoffe e.V.) (2009): Biogasmessprogramm II -61 Biogasanlagen im Vergleich. Gülzow.

GebreZgabher, S.A., M.P.M. MeuWissen und A.G.J.M. Oude LANSINK (2010): Costs of Producing Biogas at Dairy Farms in The Netherlands. In: International Journal on Food System Dynamics 1 (1): 26-35.

GigerenZeR, G. (2002): Calculated Risks: How to Know when Numbers Deceive You. Simon \& Schuster, New York.

Green, P.E. und V. SRInivasan (1990): Conjoint Analysis in Marketing: New Developments with Implications for Research and Practice. In: Journal of Marketing 54 (4): 3-19.

GRuBeR, W. (2006): Auf die Transportkosten achten! - Hof-Feld-Entfernung beeinflusst die Wirtschaftlichkeit verschiedener Substrate. In: Deutsches Maiskomitee e.V. (Hrsg.): Mais. Erfolgreich Biogas erzeugen. Deutsches Maiskomitee e.V., Bonn: 32-34.

Harwood, J., R. Heifner, K. Coble, J. Perry und A. Somwaru (1999): Managing Risk in Farming: Concepts, Research, and Analysis. Agricultural Economics Report No. AER774. Market and Trade Economics Division und Resource Economics Division, Economic Research Service, U.S. Department of Agriculture.

HeISSENHUBER, A. und S. BeRENZ (2006): Energieproduktion in landwirtschaftlichen Unternehmen. In: Darnhofer, I., Wytrzens, H.K., Walla, C. (Hrsg.): Alternative Strategien in der Landwirtschaft. Facultas Verlags- und Buchhandel AG, Wien: 135-144.

Hensher, D.A., J.M. Rose und W.H. Greene (2005): Applied Choice Analysis - A Primer. Cambridge University Press, Cambridge.

Hoyos, D. (2010): The State of the Art of Environmental Valuation with Discrete Choice Experiments. In: Ecological Economics 69 (8): 1595-1603. 
Isermeyer, F., A. Otte, O. Christen, S. Dabbert, K. Frohberg, U. GrabskiKieron, J. hartung, A. Heissenhuber, J. Hess, D. Kirschke, P.M. Schmitz, A. SpILleR, A. Sundrum, und C. THOROE (2008): Nutzung von Biomasse - Empfehlungen an die Politik. In: Berichte über Landwirtschaft, Sonderheft 216.

JANG, J. und F. OLSON (2010): The Role of Product Differentiation for Contract Choice in the Agro-food Sector. In: European Review of Agricultural Economics 37 (2): 251-273.

JUST, D.R. und S.Y. WU (2009): Experimental Economics and the Economics of Contracts. In: American Journal of Agricultural Economics 91 (5): 1382-1388.

Katchova, A.L. und M.J. MiRanda (2004): Two-step Econometric Estimation of Farm Characteristics Affecting Marketing Contracts Decisions. In: American Journal of Agricultural Economics 86 (1): 88-102.

KEY, N. (2004): Agricultural Contracting and the Scale of Production. In: Agricultural Resource Economics Review 33 (2): 255-271.

KEY, N. (2005): How Much Do Farmers Value Their Independence? In: Agricultural Economics 33 (1): 117-126.

KeY, N. und J. MACDONALD (2006): Agricultural Contracting: Trading Autonomy for Risk Reduction. In: Amber Waves 4 (1): 26-31.

KEYMER, U. (2009): Rentabilität der Biogaserzeugung - Erläuterungen, Übersichten und Musterkalkulationen zum Erneuerbaren-Energien-Gesetz (EEG). Schriftenreihe des Hauptverbandes der landwirtschaftlichen Buchstellen und Sachverständigen, Heft 183. HLBS Verlag, Sankt Augustin.

KRINSKY, I. und A.L. RoBB (1986): On Approximation the Statistical Properties of Elasticities. In: The Review of Economics and Statistics 68 (4): 715-719.

KTBL (Kuratorium für Technik und Bauwesen in der Landwirtschaft e.V.) (2009): Faustzahlen Biogas. 2. Auflage. Darmstadt.

LIST, J.A., P. SINHA und M.H. TAYLOR (2006): Using Choice Experiments to Value Non-Market Goods and Services: Evidence from Field Experiments. In: Advances in Economic Analysis \& Policy 6 (2): Artikel 2.

Loewenstein, G. (1999): Experimental Economics from the Vantage-Point of Behavioural Economics. In: The Economic Journal 109: F25-F34.

Louviere, J.J., D.A. Hensher und J.D. Swalt (2000): Stated Choice Methods. Analysis and Application. Cambridge University Press, Cambridge. 
MubHOFF, O. und N. HiRSCHAUER (2008): Investment Planning under Uncertainty and Flexibility - The Case of a Purchasable Sales Contract. In: Australian Journal of Agricultural and Resource Economics 52 (1): 17-36.

MUBHOFF, O. und N. HIRSCHAUER (2011): Was bestimmt die Akzeptanz der Landwirte für Lieferverträge? - Das Beispiel „Industrierüben“. In: Sugar Industry 136 (61): 481-491.

NLS (Niedersächsisches Landesamt für Statistik) (2001): Die Ermittlung der amtlichen Hektarerträge für Feldfrüchte in Niedersachsen und Ernteergebnisse 2001, In: http://www.nls.niedersachsen.de/Tabellen/Landwirtschaft/bee_text/e stat.htm. Abruf: 21.12.2011.

QIN, P., F. CARLSSON und J. XU (2011): Forest Tenure Reform in China: A Choice Experiment on Farmers Property Rights Preferences. In: Land Economics 87 (3): 473-487.

Reise, C., O. Mubhoff, K. Granoszewski und A. Spiller (2012): Which Factors Influence the Expansion of Bioenergy? An Empirical Study of the Investment Behaviours of German Farmers. In: Ecological Economics 73 (C): 133-141.

ROE, B.E. und D.R. JUST (2009): Internal and External Validity in Economics Research: Tradeoffs Between Experiments, Field Experiments, Natural Experiments, and Field Data. In: American Journal of Agricultural Economics 91 (5): 1266-1271.

Roe, B.E., T. L. Sporleder und B. BelleVILLE (2004): Hog Producer Preferences for Marketing Contract Attributes. In: American Journal of Agricultural Economics 86 (1): 115-123.

ROLAND, F., V. RuWISCH und K. WAGNER (2009): Grundsätze der Preisfestlegung bei Lieferverträgen für Biogasanlagen. In: http://froland.hs-harz.de/public/schwer punkte/Liefervertraege20-04-2009.pdf. Abruf: 21.08.2011.

Ruppert, H., S. Eigner-Thiel, W. Girschner, M. Karpenstein-Machan, F. ROLAND, V. RuWISCH, B. SAUER und P. SCHMUCK (2008): Wege zum Bioenergiedorf. Leitfaden für eine eigenständige Wärme- und Stromversorgung auf Basis von Biomasse im ländlichen Raum. Fachagentur für nachwachsende Rohstoffe e.V., Gülzow.

SChaper, C., C.H. EMmanN und L. Theuvsen (2011): Der Markt für Bioenergie 2011. German Journal of Agricultural Economics 60 (Supplement): 111-130. 
SCHMITZ, K., P.M. SCHMITZ und T.C.WRONKA (2003): Bewertung von Landschaftsfunktionen mit Choice Experiments. In: German Journal of Agricultural Economics 52 (8): 379-389.

SCHRÖER, S. (2010): Das Erneuerbare-Energien-Gesetz: Förderungspolitik am Scheideweg. In: Wirtschaftsdienst 90 (10): 656-660.

Schulze SteinmanN, M. und K. Holm-Müller (2010): Thünensche Ringe der Biogaserzeugung - Der Einfluss der Transportwürdigkeit nachwachsender Rohstoffe auf die Rohstoffwahl von Biogasanlagen. In: German Journal of Agricultural Economics 59 (1): 1-12.

SCHWARTZ, S.H. (1994): Are there Universal Aspects in the Structure and Content of Human Values? In: Journal of Social Issues 50 (4): 19-45.

SELTEN, R. (1990): Bounded Rationality. In: Journal of Institutional and Theoretical Economics 146 (4): 649-658.

SIMON, H.A. (1956): Rational Choice and the Structure of Environments. In: Psychological Review 63 (2): 129-138.

SPILLER, A. und B. SCHULZE (2006): Selbstbestimmte Landwirtschaft versus vertragsgebundener Rohstofflieferant: Einstellungen deutscher Landwirte zur Vertragsproduktion. Schriftenreihe „Landwirtschaft und Landschaftspflege in Thüringen“, Heft 9/2006. Thüringer Landesanstalt für Landwirtschaft, Jena: 4460.

SteffFen, N., S. Schlecht und A. Spiller (2009): Ausgestaltung von Milchlieferverträgen nach der Quote. Diskussionsbeitrag Nr. 0909. Department für Agrarökonomie und Rurale Entwicklung der Georg-August-Universität Göttingen.

STEINHORST, M.P. und E. BAHRS (2011): Die Analyse der Rationalität im Verhalten von Stakeholdern des Agribusiness anhand eines Experiments. Vortrag, gehalten auf der 51. Jahrestagung der Gesellschaft für Wirtschafts- und Sozialwissenschaften des Landbaues e.V., 28.-30.09.2011, Halle. In: http://ageconsearch. umn.edu/bitstream/114490/2/steinhorst.pdf. Abruf: 14.12.2011.

STÜRMER, E. und M. EdER (2010): Modell zur Optimierung der Substratbereitstellungskosten bei Biogasanlagen. In: Die Bodenkultur 61 (1): 39-49.

Tiedemann, T., G. Breustedt und U. Latacz-Lohmann (2011): Risikoberücksichtigung in der nicht parametrischen Effizienzanalyse: Auswirkungen auf die Effizienzbewertung von deutschen Schweinemastbetrieben. In: German Journal of Agricultural Economics 60 (4): 215-229. 
Walla, C. und W. Schneeberger (2008): The Optimal Size for Biogas Plants. In: Biomass and Bioenergy 32 (6): 551-557.

WossinK, G.A. und J.H. VAN WENUM (2003): Biodiversity Conservation by Farmers: Analysis of Actual and Contingent Participation. In: European Review of Agricultural Economics 30 (4): 461-485.

WULF, S., P. JÄGER und H. DÖHLER (2006): Balancing of Greenhouse Gas Emissions and Economic Efficiency for Biogas-production through Anaerobic Cofermentation of Slurry with Organic Waste. In: Agriculture, Ecosystems and Environment 112 (2-3): 178-185.

\section{Danksagung}

Für hilfreiche Kommentare, Anregungen und Kritik danken wir den Herausgebern des "German Journal of Agricultural Economics“, zwei anonymen Gutachtern und Holger Reise. Den Betriebsleitern danken wir für ihre Teilnahme an der Befragung. Die Befragung wurde in Kooperation mit Prof. Dr. Achim Spiller und Karol Granoszewski durchgeführt. Wir danken dem Niedersächsischen Ministerium für Wissenschaft und Kultur für finanzielle Unterstützung. 


\section{Zusammenfassende Darstellung und Diskussion}


Zentrales Anliegen der Dissertationsschrift ist die empirische Analyse von Einstellung und Entscheidungsverhalten landwirtschaftlicher Betriebsleiter bezüglich ihrer Investitions- und Bindungsbereitschaft im Hinblick auf Biogasanlagen und deren Rohstoffversorgung. Dazu sollen die durchgeführten Untersuchungen zu weiteren Erkenntnissen hinsichtlich der komplexen Entscheidungsfindungsprozesse von wirtschaftlichen Akteuren führen, Entscheidungsunterstützung auf einzelbetrieblicher Ebene leisten und im Rahmen von Politikfolgenabschätzung weitere Voraussetzungen für einen nachhaltigen Ausbau der Biogaserzeugung schaffen.

\section{Unternehmerisches Investitionsverhalten bei Biogasanlagen}

Als Schwerpunkt des ersten Bereiches der Dissertationsschrift steht die Frage im Vordergrund, welche Faktoren bei Investitionsentscheidungen in Bezug auf Biogasanlagen für landwirtschaftliche Unternehmer von Bedeutung sind. In der zur Beantwortung dieser Frage durchgeführten Untersuchung wurde angenommen, dass ein Betriebsleiter, der eine Investition in eine Biogasanlage tätigt, auch den Anbau des Substrats zur Versorgung der Anlage vornimmt. Somit geht der Betriebsleiter gewissermaßen einen Substratliefervertrag mit sich selbst ein. Der Abschluss dieses „Substratliefervertrages“ wird als Investition betrachtet, bei dem die relative Wettbewerbsfähigkeit der Substratproduktion die Kernkomponente darstellt.

An der im Sommer 2009 durchgeführten Befragung „Investitionsverhalten Bioenergie" haben 135 landwirtschaftliche Betriebsleiter teilgenommen. Die Betriebsleiter wurden im Rahmen eines ökonomischen Experiments mit einer hypothetischen Entscheidungssituation konfrontiert, in der über die Durchführung einer Investition in eine Biogasanlage mit zeitgleicher Umstellung des bestehenden Produktionsprogramms entschieden werden sollte.

Die Untersuchung bestätigt, dass Landwirte ganz unterschiedliche Investitionsschwellen für Biogasanlagen besitzen. Dies erklärt auch, warum Landwirte sehr unterschiedlich auf exogene Stimuli zur Förderung der Produktion von erneuerbaren Energien reagieren. Außerdem zeigt sich, dass die Investitionsentscheidung maßgeblich durch die Unternehmensziele "Gewinnmaximierung" und „Sicherheitsstreben“ beeinflusst wird. Eine weitere wesentliche Erklärungskomponente bildet die begrenzte Rationalität hinsichtlich der Einschätzung der Kapitalkosten. Die Kapitalkosten werden häufig unterschätzt. Dies deutet darauf hin, dass in landwirtschaftlichen Betrieben Gewinnsteigerungspotenzial aufgrund attraktiver, aber nicht realisierter und unattraktiver, aber realisierter Investitionen besteht. Die untersuchten Nachhaltigkeitseffekte hinsichtlich der langfristigen Ertragskraft des Bodens 
durch die Aufnahme von Substratanbau und außerökonomische Unternehmerzielsetzungen verfügen über einen geringen Erklärungsgehalt für die Höhe der Investitionsschwelle.

Es wurde zudem die Wirkung einer Investitionszulage untersucht, die zu einer Reduzierung der mit der Investition verbundenen Kapitalkosten führt. Die Höhe der Investitionszulage wurde im Durchschnitt nur annähernd zur Hälfte von den befragten Landwirten antizipiert. Zudem reagieren die Betriebsleiter, die zuvor in eine Biogasanlage investiert haben, viel stärker auf die Investitionszulage als Betriebsleiter, die in diesem Bereich bisher nicht tätig waren. Dies könnte zum Teil in Mitnahmeeffekten begründet sein. Sollte sich dieser Effekt auch in weiteren Studien bestätigen, so wären die in der Agrarpolitik ohnehin kritisch betrachteten Investitionsfördermaßnahmen zusätzlich in Frage zu stellen. Hinsichtlich der Politikberatung bedeuten die Ergebnisse, dass bei der Politikfolgenabschätzung berücksichtigt werden muss, dass reale Entscheider begrenzt rational handeln und sich deshalb nicht gemäß einfachen normativen Prognosemodellen an veränderte Rahmenbedingungen anpassen.

\section{Verträge für die Rohstoffversorgung von Biogasanlagen}

Bei der ersten Untersuchung wurde vereinfachend angenommen, dass eine Investition in eine Biogasanlage auch die eigenständige Substratversorgung der Anlage erfordert. Oft ist jedoch bei größeren Anlagen und Anlagenbetreibern, die über kein eigenes Substrat verfügen, eine Substrat(zu)lieferung durch Dritte notwendig. Um der zweiten Forschungsfrage bezüglich der Präferenzen landwirtschaftlicher Betriebsleiter (Substratverkäuferperspektive) hinsichtlich der Ausgestaltung von Rohstofflieferverträgen für Biogasanlagen nachzugehen, wurde eine weitere Untersuchung durchgeführt. Dazu wird die Entscheidung aus der ersten Untersuchung aufgespalten und der Fokus auf den Substratverkäufer gelegt.

Im Sommer 2011 wurde die zweite Befragung mit dem Titel „Gestaltung Substratlieferverträge“ durchgeführt. Ziel dieser Untersuchung ist es aus Perspektive der substratversorgenden Landwirte wesentliche Faktoren für den Abschluss von Maislieferverträgen zur Rohstoffversorgung von Biogasanlagen aufzuzeigen. Es haben 178 landwirtschaftliche Betriebsleiter an der Befragung teilgenommen. Von diesen hat zum Zeitpunkt der Teilnahme fast die Hälfte Substratlieferverträge abgeschlossen. Die anderen Betriebsleiter sind keine derartigen Verträge eingegangen. Die Ergebnisse zeigen, dass die Betriebsleiter, die Verträge abgeschlossen haben, in der Mehrzahl mit ihren Verträgen zufrieden sind. Zudem ergibt die 
Analyse der Gesamtstichprobe, dass die Teilnehmer einzelnen Vertragsmerkmalen unterschiedliche Bedeutung zumessen. Am wichtigsten ist der Verkaufspreis. Mittlere Bedeutung wird dem Vertragspartner und der Laufzeit zugemessen. Die Liefermenge ist nur von untergeordneter Relevanz.

Außerdem wurden den Teilnehmern - im Rahmen eines Choice-Experiments wiederholt alternative Substratlieferverträge angeboten. Die Verträge unterscheiden sich in den Ausprägungen verschiedener Vertragsmerkmale. Zur Bestimmung der jeweiligen Einflussstärke auf die Auswahlentscheidung wurden die Vertragskomponenten systematisch variiert.

Bei den untersuchten Vertragsmerkmalen konnte gezeigt werden, dass für die befragten Landwirte die Art des Vertragspartners wichtig ist. Als mögliche Vertragspartner werden andere Landwirte und Bioenergiedörfer ${ }^{4}$ gegenüber außerlandwirtschaftlichen Investoren favorisiert. Eine zunehmende Vertragslaufzeit wirkt sich negativ und ein zunehmender Verkaufspreis positiv auf die Wahrscheinlichkeit eines Vertragsabschlusses aus. Bezüglich der untersuchten Merkmale der Befragten zeigt sich, dass das Ausmaß der Wertschätzung unternehmerischer Freiheit einen Einfluss auf die Höhe der Prämie für ein zusätzliches Jahr Vertragslaufzeit hat. Die Erwartung, dass risikoaverse Landwirte - beispielsweise aufgrund von Sicherheitsüberlegungen - Festpreisverträge gegenüber Marktpreisverträgen (eine mögliche Variante einer Preisanpassungsklausel) bevorzugen, konnte nicht bestätigt werden. Des Weiteren haben sich bestehende Erfahrungen mit Substratlieferverträgen nicht in Unterschieden im Auswahlverhalten bei der Vertragswahl gezeigt.

\section{Abschließende Diskussion}

Zusammenfassend bleibt festzustellen, dass die in der ersten Untersuchung befragten landwirtschaftlichen Betriebsleiter auf die Möglichkeit einer Investition in eine Biogasanlage höchst unterschiedlich regieren. Dies zeigt sich auch in der Bandbreite der individuellen Risikoeinschätzung und der jeweiligen Bewertung von Boden- und Umwelteffekten. Im Gegensatz zu diesen individuellen Einschätzungen lassen sich die Kapitalkosten objektiv bestimmen. Die Kapitalkosten werden von den Teilnehmern unterschiedlich eingeschätzt und im Mittel stark unterschätzt. Diese Unterschätzung könnte auch dafür mitverantwortlich sein, dass die untersuchte Investitionszulage im Durchschnitt nur etwa zur Hälfte ihres Betrages ihre

4 „In einem Bioenergiedorf wird das Ziel verfolgt, möglichst die gesamte Wärme- und Stromversorgung eines Ortes auf Basis des erneuerbaren Energieträgers „Biomasse“ zu stellen und die Bioenergieanlagen in Eigenregie zu betreiben." (RUPPERT et al. 2008:10). 
Wirkung entfaltet. Unter Effizienzgesichtspunkten erscheint dies bedenklich, da jedem Euro Fördermittel ein möglichst hoher Betrag an „ausgelöster Investitionssumme" gegenüberstehen sollte. Die Ergebnisse deuten an, wie vielfältig die Entscheidungsgrundlagen wirtschaftlicher Akteure in der Realität sind und zeigen weiteren Forschungsbedarf auf. Im Rahmen einer Politikfolgenabschätzung sollte bei Fördermaßnahmen zugunsten der Biogaserzeugung die begrenzte Rationalität von realen Entscheidern berücksichtigt werden. Neben der Angabe von relativen und absoluten Fördergrößen könnten beispielsweise Musterkalkulationen eine zutreffendere Einschätzung unterstützen.

Bei Anlagenbetreibern, die nicht über ausreichend (eigenes) Substrat verfügen, sind im Rahmen der Investitionsentscheidung Verträge für die Rohstoffversorgung zu berücksichtigen. Die Untersuchung zu Substratlieferverträgen zeigt, dass die Mehrzahl der Teilnehmer, die derartige Verträge als Verkäufer abgeschlossen hat, mit diesen zufrieden ist. Für einen weiteren Ausbau von Biogasanlagen werden jedoch zusätzliches Substrat bzw. diesbezügliche Lieferverträge benötigt. Die Einschätzung der befragten Betriebsleiter - in Form einer Rangfolge - zeigt, dass den einzelnen Merkmalen eines solchen Vertrages unterschiedliche Bedeutung zukommt. Mithilfe des Choice Experiments konnten ausgewählten Vertragsmerkmalen implizite Preise zugeordnet werden. Des Weiteren zeigt sich die Notwendigkeit einer Berücksichtigung von Merkmalen der Befragten, wie beispielsweise die individuelle Bedeutung von unternehmerischer Freiheit. Die Ergebnisse können sowohl für Substratverkäufer als auch für Substratankäufer hilfreich sein und als Anregung bei der Ausarbeitung von Verträgen bzw. in Vertragsverhandlungen dienen.

Wenn in der Zukunft der Anteil fossiler Energieträger an der Stromversorgung immer weiter zurückgeht, muss eine Kombination aus Erneuerbaren Energien zunehmend die Grundlast übernehmen. Aufgrund der Speicherbarkeit von Energie aus Biogas spielt diese somit im zukünftigen Strommix eine bedeutende Rolle (BMWı und BMU 2010: 10). Neben der Umstellung der Energieträger kommt der effizienten Nutzung von Energie eine Schlüsselrolle zu, da nicht benötigte Energie weder erzeugt noch transportiert werden muss (BMW। 2012: 41). Insbesondere in Anbetracht einer (global) zunehmenden Bevölkerung scheint eine relative Reduzierung notwendig. Es bleibt viel zu tun: „Was kommt, soll so sein, dass es bleiben kann; nachfolgenden Generationen sollen Chancen und Entwicklungsmöglichkeiten offenstehen und nicht durch Altlasten vordefiniert sein" (HABER 2010: 9). 


\section{Literaturverzeichnis}

AGEB (Arbeitsgemeinschaft Energiebilanzen e.V.) (2012): Primärenergieverbrauch - Jahr 2011. In: http://www.ag-energiebilanzen.de/viewpage.php?idpage=62. Abruf: 8.03.2012.

BERG, D. (1991): Shipwreck Diving: A Complete Diver's Handbook to Mastering the Skills of Wreck Diving. New York: Aqua Explorers.

BMU (Bundesministerium für Umwelt, Naturschutz und Reaktorsicherheit) und BMELV (Bundesministerium für Ernährung, Landwirtschaft und Verbraucherschutz) (2009): Nationaler Biomasseaktionsplan für Deutschland. Beitrag der Biomasse für eine nachhaltige Energieversorgung. Berlin und Bonn.

BMWI (Bundesministerium für Wirtschaft und Technologie) (2012): Die Energiewende in Deutschland. Mit sicherer, bezahlbarer und umweltschonender Energie ins Jahr 2050. Berlin.

BMWI (Bundesministerium für Wirtschaft und Technologie) und BMU (Bundesministerium für Umwelt, Naturschutz und Reaktorsicherheit) (2010): Energiekonzept für eine umweltschonende, zuverlässige und bezahlbare Energieversorgung. Berlin.

HABER, W. (2010): Die unbequemen Wahrheiten der Ökologie: Eine Nachhaltigkeitsperspektive für das 21. Jahrhundert. München: Oekom-Verlag.

MU (Niedersächsischen Ministerium für Umwelt, Energie und Klimaschutz) (2012): Biomasse. In: http://www.umwelt.niedersachsen.de/portal/live.php?navigation_id $=2627 \&$ article_id=8524\&_psmand=10. Abruf: 8.03.2012.

Ruppert, H., S. Eigner-Thiel, W. Girschner, M. Karpenstein-Machan, F. ROLAND, V. RUWISCH, B. SAUER und P. SCHMUCK (2008): Wege zum Bioenergiedorf. Leitfaden für eine eigenständige Wärme- und Stromversorgung auf Basis von Biomasse im ländlichen Raum. Gülzow: Fachagentur für nachwachsende Rohstoffe e.V.

Walla, C. und W. Schneeberger (2008): The Optimal Size for Biogas Plants. In: Biomass and Bioenergy 32 (6): 551-557. 


\section{Erklärung über den geleisteten Eigenanteil an der Arbeit}

In dem Beitrag „Which Factors Influence the Expansion of Bioenergy? An Empirical Study of the Investment Behaviours of German Farmers" der in Zusammenarbeit mit Prof. Dr. Oliver Mußhoff, Karol Granoszewski und Prof. Dr. Achim Spiller verfasst wurde, wurden folgende Bereiche von mir übernommen: Idee und Konzeption der Untersuchung und Aufstellung des Modells mit Beratung durch Oliver Mußhoff, Durchführung der Befragung mit Oliver Mußhoff, Karol Granoszewski und Achim Spiller, Analyse und Interpretation der Ergebnisse in enger Zusammenarbeit mit Oliver Mußhoff.

In dem Beitrag „Präferenzen von Landwirten bei der Gestaltung von Substratlieferverträgen für Biogasanlagen: Ein Choice-Experiment“ der in Zusammenarbeit mit Jun.-Prof. Ulf Liebe und Prof. Dr. Oliver Mußhoff verfasst wurde, wurden folgende Bereiche von mir übernommen: Idee und Konzeption der Untersuchung und Aufstellung des Modells mit Beratung durch Oliver Mußhoff und Ulf Liebe, Durchführung der Befragung in Kooperation mit Oliver Mußhoff, Karol Granoszewski und Achim Spiller, Analyse und Interpretation der Ergebnisse in enger Zusammenarbeit mit Ulf Liebe und Oliver Mußhoff. 


\section{Publikationsverzeichnis}

Reise, C.; Korf, J.; Liebe, U.; Mußhoff, O.: Was sind die wichtigsten Entscheidungsgrößen beim Abschluss von Substratlieferverträgen?. In: DLG-Mitteilungen (im Druck).

Reise, C.; Liebe, U.; Mußhoff, O.: Präferenzen von Landwirten bei der Gestaltung von Substratlieferverträgen für Biogasanlagen: Ein Choice-Experiment. In: German Journal of Agricultural Economics (im Druck).

Reise, C.; Liebe, U.; Mußhoff, O. (2012): Design of substrate supply contracts for biogas plants. 56th Annual Conference: Australian Agricultural \& Resource Economics Society (AARES), 7th - 10th February 2012 in Fremantle, Western Australia.

Reise, C.; Mußhoff, O.; Granoszewski, K.; Spiller, A. (2012): Which Factors Influence the Expansion of Bioenergy? An Empirical Study of the Investment Behaviours of German Farmers. In: Ecological Economics 73 (C): 133-141.

Granoszewski, K.; Reise, C.; Spiller, A.; Mußhoff, O. (2011): The Role of Land Use Competition in Farmers' Engagement in Renewable Energy Production. In: Senesi, S; Zylbersztajn, D. and F. Vilella (Eds.): The Proceedings of the VIIlth International Agribusiness PAA-PENSA Conference, November, 30th - December, 2nd 2011, The Food and Agribusiness Program (PAA) and PENSA Association, Buenos Aires, Argentina.

Granoszewski, K.; Reise, C; Spiller, A.; Mußhoff, O. (2011): Die Relevanz landwirtschaftlicher Konflikte im Kontext zunehmender Biogaserzeugung. In: Hambrusch, J., Larcher M. und T. Oedl-Wieser (Hrsg.): Jahrbuch der Österreichischen Gesellschaft für Agrarökonomie 20 (2), Wien: Facultas. 
Granoszewski, K.; Spiller, A.; Reise, C.; Mußhoff, O. (2011): The Influence of Land Use Competition on the Expansion of Bioenergy Production: A Case Study of German Agriculture. In: Columbia University, Earth Institute (Eds.): The Abstracts of 17th Annual International sustainable Development Research Conference, 8th 10th May 2011, International Sustainable Development Research Society, Columbia University, Earth Institute, New York.

Granoszewski, K.; Spiller, A.; Reise, C.; Mußhoff, O. (2011): Die Diffusion regenerativer Energien in der deutschen Landwirtschaft - Investitionsverhalten in einem politisch induzierten Markt. In: Andreani, J.-C. and U. Collesei (Eds.): The Proceedings of 10th International Conference Marketing Trends, 20th - 22nd January 2011, International Marketing Trends Association, Paris.

Granoszewski, K.; Lammers, C.; Mußhoff, O.; Reise, C.; Spiller, A. (2011): Investitionsmöglichkeit Biogas: Was beeinflusst die Entscheidung? In: Neue Landwirtschaft 01/2011: 72-75.

Granoszewski, K.; Reise, C.; Spiller, A.; Mußhoff, O. (2010): Konfliktpotenziale der Biogaserzeugung in der Landwirtschaft - eine Situationsanalyse. Vortrag im Rahmen der 20. ÖGA-Jahrestagung am 23. - 24. September 2010, Universität für Bodenkultur (BOKU), Wien.

Reise, C.; Mußhoff, O.; Granoszewski, K.; Spiller, A. (2010): Does Bounded Rationality have an Impact on the Decision to Invest in Bioenergy? 11th Biennial Conference: "Advancing Sustainability in a Time of Crisis", International Society for Ecological Economics (ISEE), 22nd - 25th August 2010 in Oldenburg and Bremen, Germany.

Reise, C.; Mußhoff, O.; Granoszewski, K.; Spiller, A. (2010): Decision Behavior Regarding Investments in Biogas Plants - An Empirical Study of German Farmers. III Workshop on Valuation Methods in Agro-food and Environmental Economics: "Decisions and Choices Under Uncertainty in Agro-food and Natural Resources Economics", Centre for Research on Agro-food and Development Economics-UPCIRTA (CREDA), together with the European Association of Agricultural Economics (EAAE), the Spanish Association of Agricultural Economics (AEEA), and the Spanish-Portuguese Association of Natural Resources and Environmental Economics (AERNA), 1th - 2nd July 2010 in Barcelona, Spain. 
Reise, C.; Mußhoff, O.; Granoszewski, K.; Spiller, A. (2010): Spielt begrenzte Rationalität bei Investitionsentscheidungen in Bioenergie eine Rolle? In: Claupein, W.; Theuvsen, L.; Kämpf, A.; Morgenstern, M. (Hrsg.): Precision Agriculture Reloaded - Informationsgestützte Landwirtschaft. GI-Edition Lecture Notes in Informatics (LNI) Proceedings, Vol. P 158: 143 146, Bonn: Köllen Druck + Verlag $\mathrm{GmbH}$.

Granoszewski, K.; Reise, C.; Spiller, A.; Mußhoff, O. (2009): Entscheidungsverhalten landwirtschaftlicher Betriebsleiter bei Bioenergieinvestitionen Erste Ergebnisse einer empirischen Untersuchung. Göttingen: Diskussionspapier Nr. 0911, GeorgAugust-Universität Göttingen, Fakultät für Agrarwissenschaften, Department für Agrarökonomie und Rurale Entwicklung. 


\section{Eidesstattliche Erklärung}

1. Hiermit erkläre ich, dass diese Arbeit weder in gleicher noch in ähnlicher Form bereits anderen Prüfungsbehörden vorgelegen hat.

Weiter erkläre ich, dass ich mich an keiner anderen Hochschule um einen Doktorgrad beworben habe.

Göttingen, den

(Unterschrift)

2. Hiermit erkläre ich eidesstattlich, dass diese Dissertation selbstständig und ohne unerlaubte Hilfe angefertigt wurde.

Göttingen, den

(Unterschrift) 